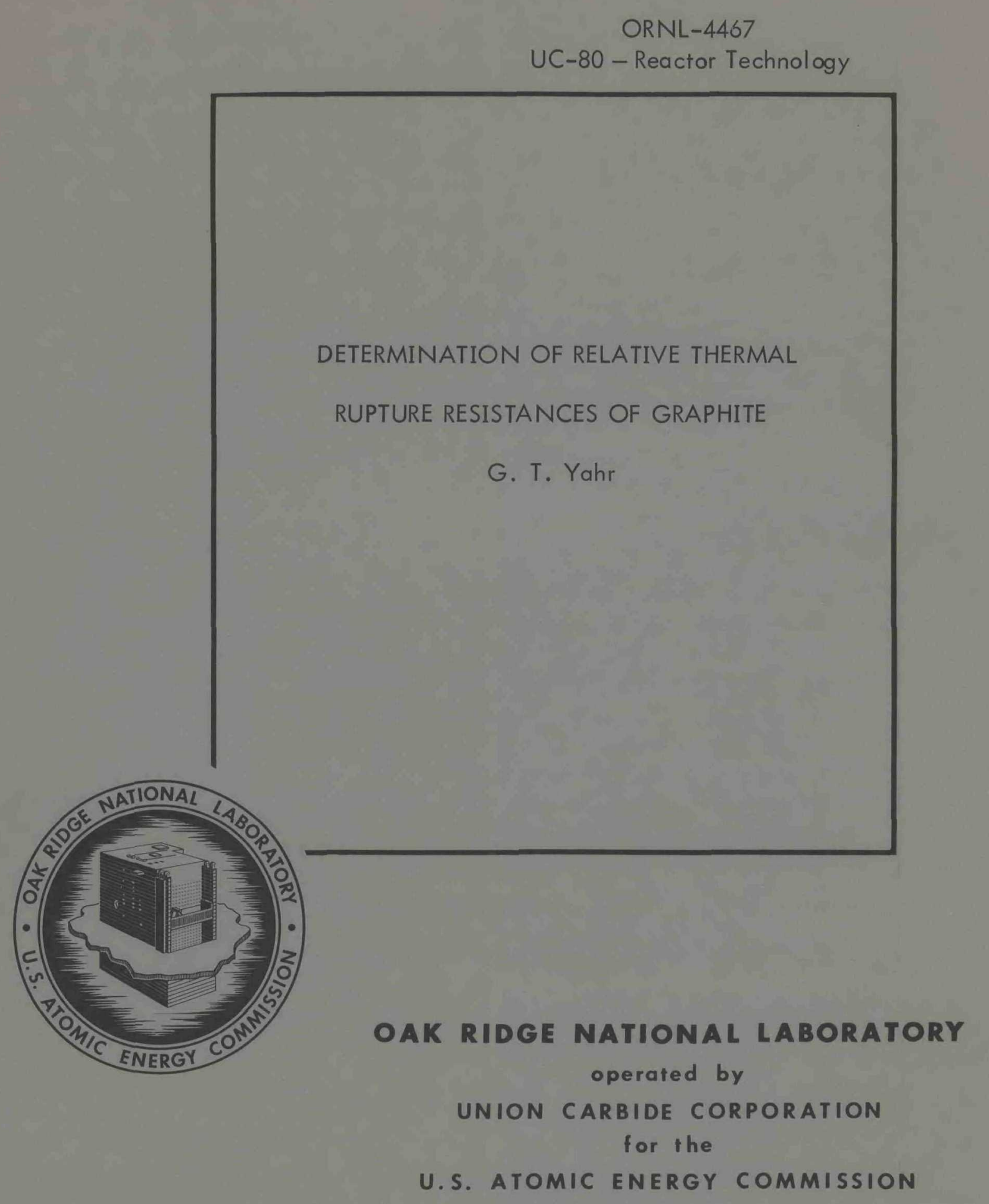


Printed in the United States of America. Available from Clearinghouse for Federal

Scientific and Technical Information, National Bureau of Standards,

U.S. Department of Commerce, Springfield, Virginia 22151

Price: Printed Copy $\$ 3.00$; Microfiche $\$ 0.65$

LEGAL NOTICE

This report was prepared as an account of Government sponsored work. Neither the United Stotes, nor the Commission, nor any person acting on behalf of the Commission:

A. Makes any warranty or representation, expressed or implied, with respect to the accuracy, completeness, or usefulness of the information contained in this report, or that the use of any information, apparatus, method, or process disclosed in this report may not infringe privately owned rights; or

B. Assumes any liabilities with respect to the use of, or for damages resulting from the use of any information, apparatus, method, or process disclosed in this report.

As used in the above, "person acting on behalf of the Commission" includes any employee or contractor of the Commission, or employee of such contractor, to the extent that such employee or contractor of the Commission, or employee of such contractor prepares, disseminates, or provides access to, any information pursuant to his employment or contract with the Commission or his employment with such contractor. 


\section{DISCLAIMER}

Portions of this document may be illegible in electronic image products. Images are produced from the best available original document. 


\section{DISCLAIMER}

This report was prepared as an account of work sponsored by an agency of the United States Government. Neither the United States Government nor any agency Thereof, nor any of their employees, makes any warranty, express or implied, or assumes any legal liability or responsibility for the accuracy, completeness, or usefulness of any information, apparatus, product, or process disclosed, or represents that its use would not infringe privately owned rights. Reference herein to any specific commercial product, process, or service by trade name, trademark, manufacturer, or otherwise does not necessarily constitute or imply its endorsement, recommendation, or favoring by the United States Government or any agency thereof. The views and opinions of authors expressed herein do not necessarily state or reflect those of the United States Government or any agency thereof. 
Contract No. W-7405-eng-26

\author{
Reactor Division
}

\title{
DETERMINATION OF RELATIVE THERMAL RUPTURE RESISTANCES OF GRAPHITE
}

G. T. Yahr

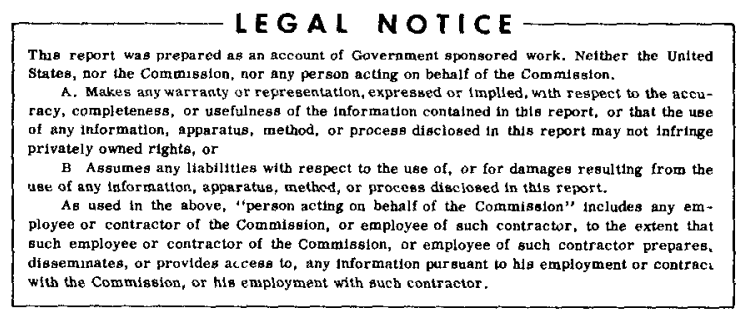

JANUARY 1970

OAK RIDGE NATIONAL LABORATORY

Oak Ridge, Tennessee

operated by

UNION CARBIDE CORPORATION

for the

U.S. ATOMIC ENERGY COMMISSION 
-

\section{.}




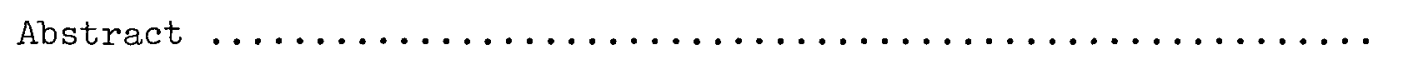

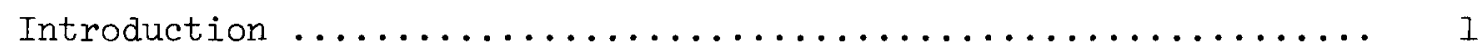

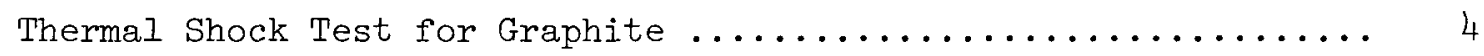

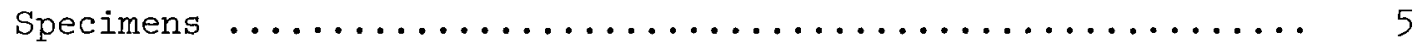

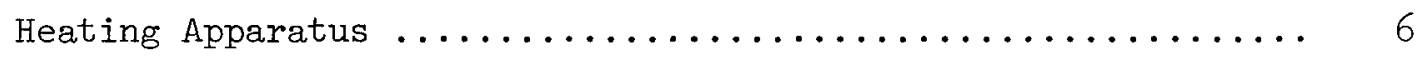

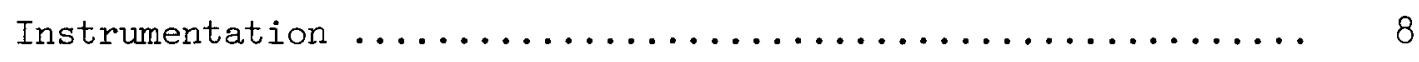

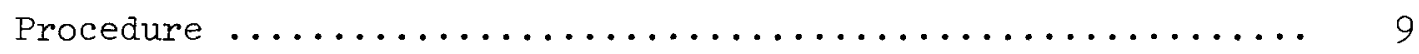

Method for Determining Threshold Power Level

for Thermal Rupture ........................ 13

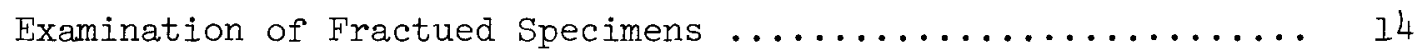

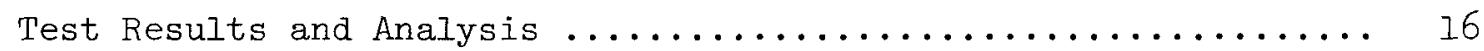

Comparison with Figures of Merit ..................... 23

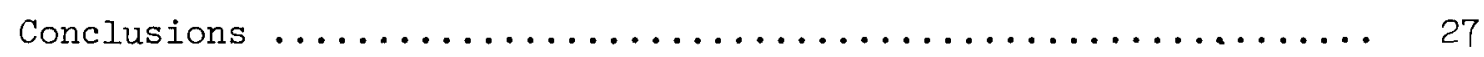

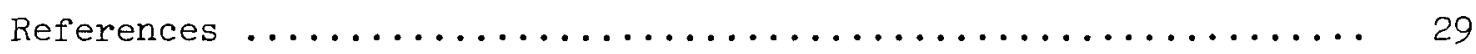

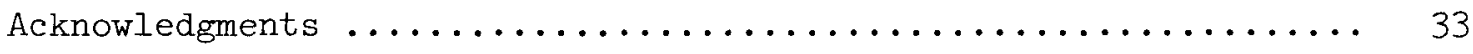

Appendix A. Properties of the Graphites Investigated ........ 35 
DETERMINATION OF RELATIVE THERMAL RUPTURE RESISTANCES OF GRAPHITES*

G. T. Yahr

Abstract

Polycrystalline graphite, which is used as a material for high-temperature application by the nuclear and aerospace industries, has remarkable resistance to thermal-stress-induced fracture. Nevertheless, certain applications tax its thermal rupture resistance, and selection of a particular grade of graphite for such an application must therefore include consideration of this property. Currently the type and grade of graphite are often selected on the basis of figures of merit that have evolved from elastic analyses, since the thermal shock tests that have been developed are too expensive to be used as screening devices.

The thermal shock test described in this report is rapid enough and sufficiently economical to be used for screening candidate materials for a particular application. The test consists of heating thin disks of graphite at the center with an inert-gas shielded-arc nonconsumable electrode welder. Several disks of each graphite are heated, each at a different, but constant, power level. The minimum power input to the welder that will consistently cause the graphite to fracture is determined. The graphite that requires the highest power level to produce a fracture is the one most resistant to thermal shock.

Twenty-one grades, or types, of graphite were ranked according to thermal shock resistance by using this test. Mechanical and thermal properties of the specimens were obtained from the literature so that figures of merit ratings could also be determined, and none of the standard figures of merit gave reliable predictions of the relative thermal shock resistances of the graphites.

Keywords: Graphite, thermal shock, thermal rupture, rupture resistance test, figures of merit, fracture, threshold power level.

\section{Introduction}

Graphite has unique properties that prompt its use in such advanced systems as rockets ${ }^{1}$ and nuclear reactors. ${ }^{2}$ One of the principal reasons

*This document was originally prepared in partial fulfillment of the requirements for the Degree of Master of Science at the University of Tennessee. The work was performed at the Oak Ridge National Laboratory. 
for its use is its ability to withstand severe thermal environments. Graphite does not melt under atmospheric pressure, but it does sublime when heated to $6500^{\circ} \mathrm{F}$. Although graphite has little tensile strength at room temperature, its strength increases as the temperature increases up to approximately $4500^{\circ} \mathrm{F}$, instead of decreasing as is typical for most materials. In addition to being one of the strongest available materials for extreme high-temperature application, it is the most thermal-stressresistant refractory material. Its thermal stress resistance is due to the low modulus of elasticity, low coefficient of thermal expansion, and high thermal conductivity, as well as the good high-temperature strength. Although graphite is extremely thermal shock resistant, thermal shock failure is of concern in certain applications. Ideally, the relative suitabilities of various types of graphite for a particular application would be determined either by testing under conditions that duplicate service conditions or by an analysis that accurately describes the material behavior, the component geometry, and the interaction of the component with its environment. In most cases, however, the ideal methods for evaluating the relative suitabilities are expensive and complicated, if possible at all. The difficulty of performing accurate analyses has been discussed by Derby. ${ }^{3}$

Figures of merit, such as $k \sigma_{f} / \alpha E$, where $k$ is the thermal conductivity, $\sigma_{f}$ is the tensile strength, $\alpha$ is the coefficient of thermal expansion, and $\mathrm{E}$ is the modulus of elasticity, have been used for determining the relative thermal shock resistances of graphites. ${ }^{4}$ However, consideration of the variation of properties with temperature and the plasticity of graphite at high temperatures casts doubt on their validity. Kendall and $\mathrm{McClelland}{ }^{5}$ summarized the present situation in a recent discussion of nonmetallic materials for aerospace applications, as follows:

The ability of graphite to withstand thermal shock is often the determining criterion in materials selection. However, attempts to predict the relative thermal-shock behavior of various graphite grades using the classical four factor formula have been unsatisfactory.

The basis of the figures of merit is the observation that the material properties always enter into the final equations for stresses as a constant multiplier in thermoelastic analyses when the heat transfer rate 
is of the same order of magnitude regardless of the geometry. This observation also justifies the selection of thermal-shock-resistant graphites with a simple thermal shock test that only approximates the service conditions. One of the purposes of this investigation was, accordingly, to test the validity of figures of merit by comparing them with ratings obtained from thermal shock tests. The advantages of the thermal shock test are that the variation of properties with temperature and plasticity are automatically taken into account and only one quantity, thermal shock resistance, must be measured.

Several types of single-cycle thermal shock tests and steady-state thermal stress tests have been used to determine the thermal stress resistance of brittle materials. ${ }^{6-9}$ However, few of the thermal stress tests have been successfully applied to graphite.

Crocker ${ }^{10,11}$ conducted a series of thermal stress tests on both KS graphite and uranium-impregnated graphite in which the specimens were 12-in.-long circular cylinders, $3 / 4$ to 1 in. in diameter, with a $1 / 8$ - to 3/16-in.-diam hole in the center. The specimens were electrically heated by their own resistance. A temperature gradient was established across the walls by flowing nitrogen through the coaxial hole in the specimens. A maximum surface temperature of $2500^{\circ} \mathrm{F}$ was maintained in a nitrogen atmosphere of 500 psi. A maximum net power of $2430 \mathrm{w} / \mathrm{in}$. was used with a nitrogen flow rate of $600 \mathrm{lb} / \mathrm{hr}$. None of the specimens broke.

Powell and Massier ${ }^{12}$ ran a series of thermal stress tests on commercial graphite of three types. Their specimens were 1/8-in.-thick 3/4-in.wide 7-in.-long plates mounted in a passage with blackened water-cooled mild-steel walls. The specimen was resistance heated, and the temperature difference was obtained with pure nitrogen flowing through the passage. Thermal stress fractures were induced at surface temperatures between 3200 and $5100^{\circ} \mathrm{F}$. An obvious advantage of this test was the ability to control independently the specimen surface temperature and temperature distribution, since a range of conditions could thus be studied. The primary disadvantages were the undetermined mechanical stress in the specimen and the difficulty of accurately computing the thermal stresses. 
Corum and Dodge ${ }^{13}$ investigated the feasibility of thermal rupture tests on graphite specimens with simple geometric shapes. They recommended a thick-walled cylinder heated by electrical resistance and cooled on the outer surface. Their parameter study indicated that the larger the ratio of outside-to-inside radius the less power would be required for fracture.

Carlsen ${ }^{14}$ heated graphite spheres in vacuum in a graphite resistance furnace to temperatures as high as $4000^{\circ} \mathrm{F}$ and then quenched them in a graphite crucible at room temperature. The spheres were $11 / 2$ and 2.36 in. in diameter, and most were graphite shells containing a uranium-loaded core or solid spheres of uranium-loaded graphite. Cracks were produced in a number of the spheres. Solid spheres of CS-312 graphite were tested but did not fail.

Bohn and $\mathrm{King}^{15,16}$ developed a thermal shock apparatus based on an electron-beam heat source. The specimens were 0.5-in.-long cylinders with an inside diameter of 1 in. and an outside diameter of $1.5 \mathrm{in}$. that were heated very rapidly on the inner surface. The tests were made on ATJ, AXF-5Q, AXF-9Q, and PO3 graphites, and none of the specimens cracked during testing. These tests were valuable, however, because both temperature and strain measurements were recorded.

None of these methods are economically suitable for determining the relative thermal stress resistance of a large number of types of graphite. Corum and Dodge's calculations of the power required to get a steady-state temperature gradient large enough to fracture graphite indicated that a transient test would be more suitable. Such a test is described in this report.

\section{Thermal Shock Test for Graphite}

The excellent resistance of graphite to thermal stresses necessitates a very severe test to produce failure. In the test described here a thin disk of graphite is heated at the center so that a radial temperature distribution is produced that can cause the disk to fracture at the rim. The geometry is simple and the elastic analysis can be readily made. ${ }^{17}$ 
In preliminary tests to determine whether disks could be heated fast enough to produce fracture, a plasma torch was used to heat the specimen. The specimens were $43 / 8 \mathrm{in}$. in diameter and varied in thickness from $1 / 4$ to $1 / 2$ in. A hole was drilled in the center of most specimens so the plasma jet could be directed through the hole and the axial temperature gradient would be a minimum. The holes were $3 / 8$ to $3 / 4 \mathrm{in}$. in diameter.

The first specimens were soaked in liquid nitrogen just prior to testing so that the test would be as severe as possible. This increased the possibility of thermal rupture because (1) the thermal conductivity of graphite decreases rapidly at subzero temperatures and thus produces a steeper temperature gradient in the disk, and (2) the strength and plasticity of graphite increase at elevated temperatures. Precooling of the specimens was later found to be unnecessary, however.

Two grades of graphite, RVA and AGOT, were cracked in these early experiments with the plasma torch, which successfully demonstrated that graphite disks could be cracked by thermal stress alone. On hearing of these results, R. N. Lyon of ORNL suggested that an arc welder might be used as an alternate heat source, and the inert-gas shielded-arc nonconsumable-electrode welder was ultimately chosen as the heat source.

The tests with the welder as the heat source give a direct measure of the relative resistances of graphites to thermal stresses. The thin disks are heated at the center so that the center becomes extremely hot before the temperature of the circumference increases appreciably. Several disks of each graphite are heated, each at a different, but constant, power level, and the minimum power input to the welder that will consistently cause the graphite to fracture is determined. The thermal shock resistance is directly related to the power level required to produce fracture.

Specimens

The test specimens were thin circular disks 2 in. in diameter and $0.10 \mathrm{in}$. thick that are ground flat and parallel to within \pm 0.0005 in. total indicator runout. The circumference has a root-mean-square roughness height of $63 \mu \mathrm{in}$. Approximately 30 specimens were needed for an 
adequate determination of the thermal shock resistance of each type graphite. Two other specimen sizes, 4 and $3 / 4 \mathrm{in}$. in diameter, with thicknesses of 0.20 and 0.05 in., respectively, were also used. The tolerances for these specimens were the same as for the 2-in. specimens.

\section{Heating Apparatus}

A schematic drawing of the power circuit used for the tests is shown in Fig. 1. Direct-current power was supplied from commercially available

ORNL-DWG 69-1993

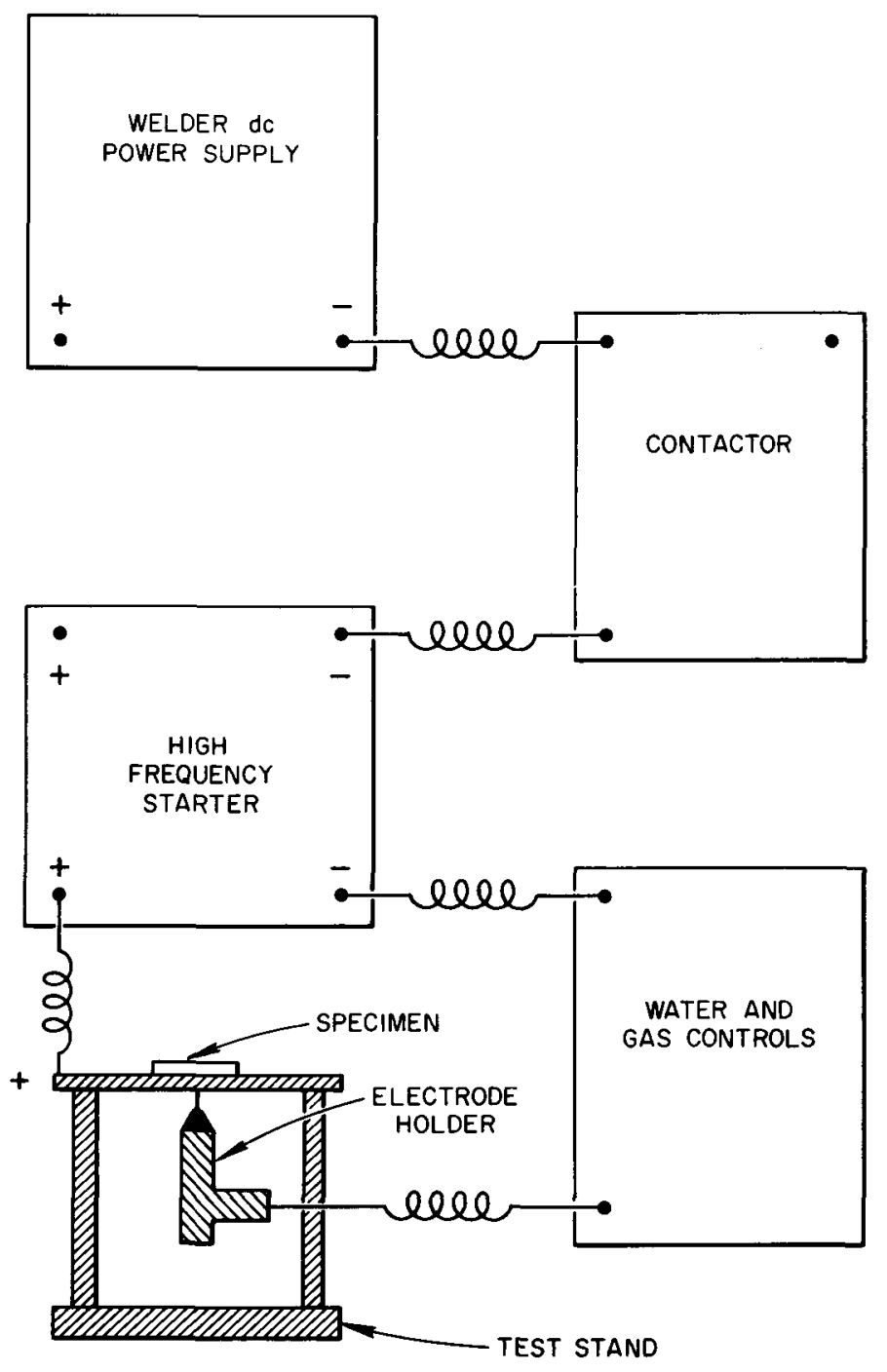

Fig. 1. Schematic Diagram of Power Circuit for Thermal Shock Test. 
welder power supply units. The standard test installation, which was used for testing the 2- and 4-in.-diam specimens, had two Miller directcurrent arc welders, Model SR 300, that could be hooked in series to deliver up to 20,000 $\mathrm{w}$ of power. The lowest power at which an are could be sustained was $1700 \mathrm{w}$. A second test installation had a Revere automatic gun welder with a working range from 200 to $5500 \mathrm{w}$ as the power source. The 3/4-in.-diam specimens were tested with the Revere welder as the heat source.

Direct-current straight polarity was used so that most of the heat was produced in the specimen rather than in the electrode; that is, the electrode was negative while the specimen was positive. Hence, the electrons struck the specimen with high velocity and imparted their energy to the specimen.

A thoriated-tungsten electrode was held in a water-cooled Heliarc electrode holder. A flat-ended 3/16-in.-diam electrode was used for testing the 2-in.-diam specimens. The electrode used for testing the 4-in.diam specimens was also flat-ended but was $1 / 4$ in. in diameter to carry the higher currents necessary for testing the 3-in.-diam specimens. A pointed 1/8-in.-diam electrode was used for testing the 3/4-in.-diam specimens.

The specimen was supported by a copper plate with a hole in it that was slightly smaller than the specimen diameter. A circle of the same diameter as that of the specimen was scribed on the top of the plate concentric with the hole so the specimens could be accurately centered over the hole. Each size specimen required a different support plate. The plate used for testing the standard 2-in.-diam specimens had a $13 / 8-i n .-$ diam hole in it. It was important that the plate and specimen both be flat to maintain good electrical contact during a test to prevent arcing. Steel rings $2 \mathrm{in.} O D$ by $13 / 8 \mathrm{in.}$ ID by $3 / 8 \mathrm{in.} \mathrm{Iong} \mathrm{were} \mathrm{placed} \mathrm{on} \mathrm{top}$ each 2-in.-diam specimen to keep it in adequate contact with the plate. The 3/4-in.-diam specimens were held in contact with the support plate by a vacuum pump attached to the hole ( $3 / 8$ in. in diameter) under the specimen.

The support plate for testing the 4-in.-diam specimens had a $31 / 2-$ in.-diam hole. The 4-in. specimens were heavy enough to insure adequate electrical contact between the specimen and plate. The plates were 
water-cooled to maintain them at the same temperature for every test. Otherwise, the plate would have become hot and after several specimens had been tested, the plate would have heated the specimen before the arc was initiated.

The electrode holder was clamped into position to insure that the center line of the electrode coincided with the center of the disk and was perpendicular to the flat face of the disk. The electrode was below the 2- and 4-in.-diam specimens but was above the 3/4-in.-diam specimens. Before each test, the electrode tip was positioned $0.25 \mathrm{in}$. from the surface of the 2- and 4-in.-diam specimens. It was $0.075 \mathrm{in}$. from the 3/4in.-diam specimens. After a commercial high-frequency starter initiated it the arc was self-sustaining.

Helium and argon are the two gases most commonly used in the inertgas shielded-arc nonconsumable electrode welding process. Although a hotter arc is produced with helium, it is easier to maintain an arc at low power with argon. Helium at a flow rate of 50 cfh was used with the Miller power supply to test the 2- and 4-in.-diam specimens. Argon at a flow rate of $30 \mathrm{cfh}$ was used with the Revere welder to test the 3/4-in.-diam specimens.

Figures 2 and 3 show 2- and 3/4-in.-diam specimens in position. The test stands are enclosed in a booth during tests to protect personnel from the flash of the arc.

Instrumentation

The current and voltage output of the welder were recorded on a strip chart during each test. A typical strip chart is shown in Fig. 4. The current trace lags the voltage trace a distance approximately equal to $7 \mathrm{sec}$. The numbers 2670 to 2675 designate the specimen numbers. In the tests recorded in Fig. 4, and, in fact, in most tests, the specimens failed violently by breaking into two or more pieces that were often thrown off the support plate. This caused a sudden increase in arc voltage. The current and voltage maintained reasonably constant values once the arc stabilized, which usually took less than I sec. Specimen 2673 (see Fig. 4 ) broke $13 \mathrm{sec}$ after the arc was initiated. The only specimen (Fig. 4) 


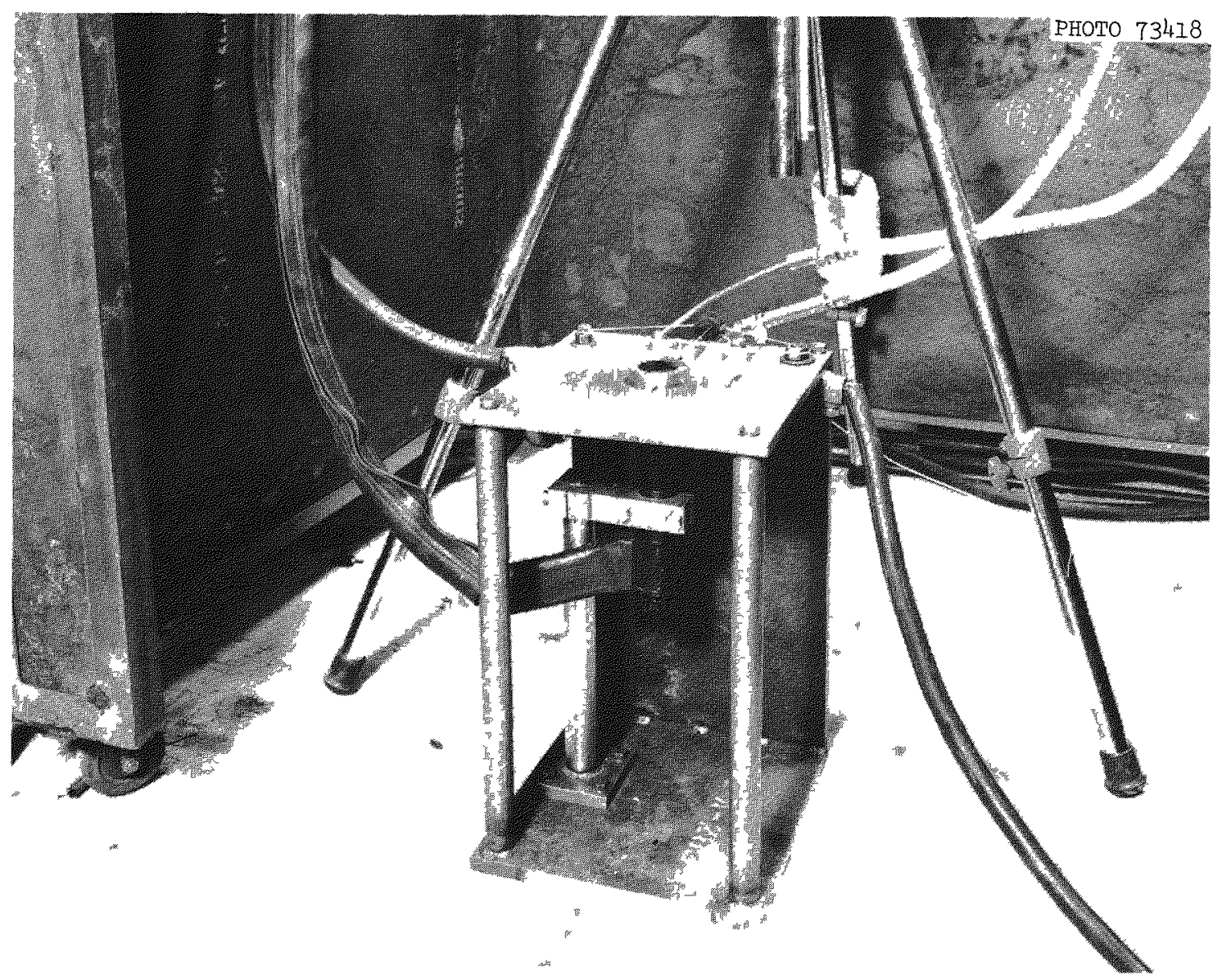

Fig. 2. Test Rig for 2-in.-diam Specimens.

that did not break was specimen 2674. The power output from the welder was determined by multiplying the values of current and voltage read from the strip chart. This power level supplied the criterion for measuring the severity of the test.

\section{Procedure}

The procedure for determining the relative thermal shock resistances is illustrated by the data of Table 1 for 2-in.-diam specimens of P03 graphite. The specimens are listed according to increasing test power level. The run numbers indicate the order in which the specimens were tested. The welder setting is the nominal value of welder current at which the welder was set. The time is the time during which the arc was 


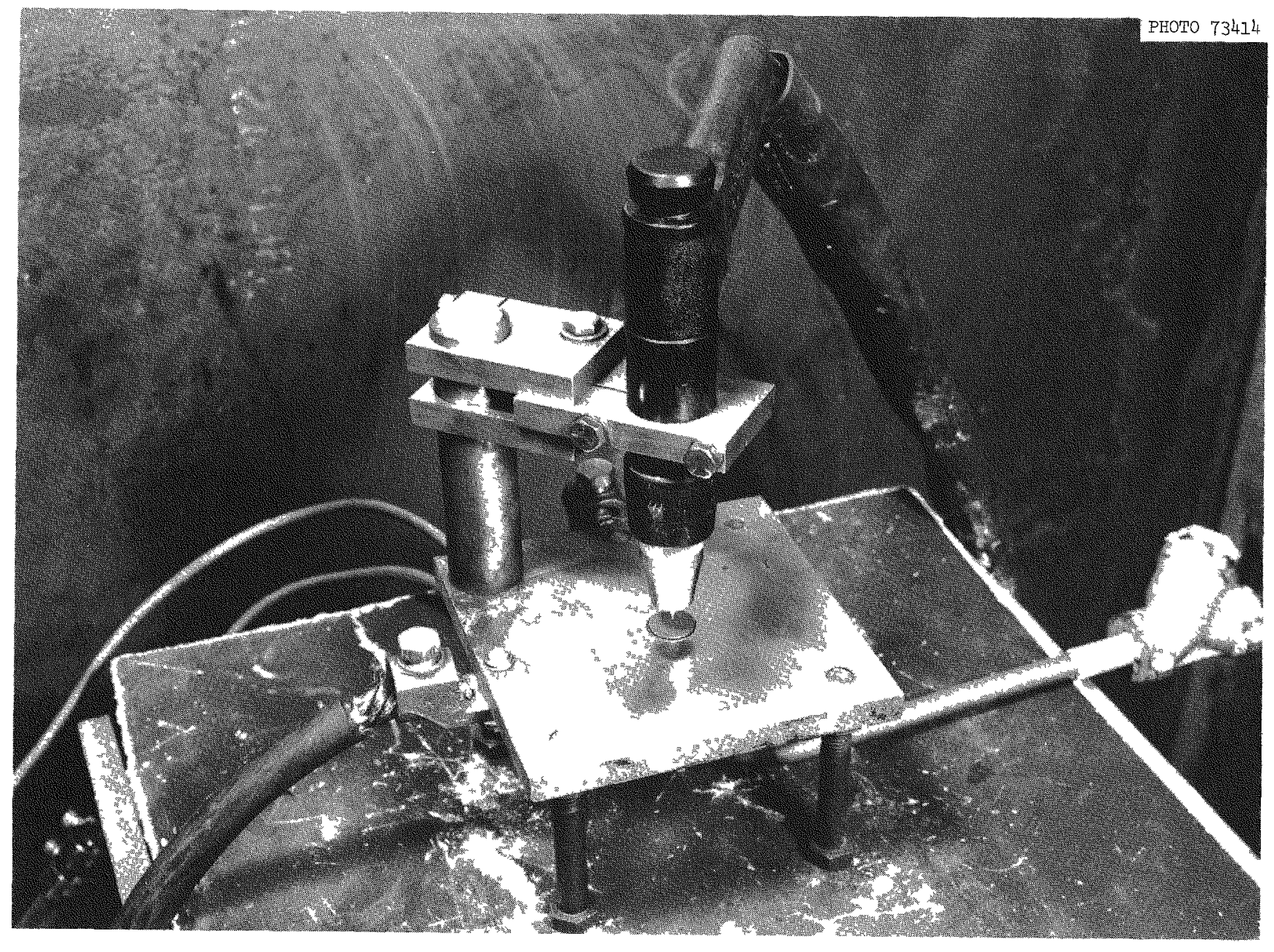

Fig. 3. Test Rig for 3/4-in.-diam Specimens. 
Table 1. Thermal Shock Data for 2-in.-diam P03 Graphite Specimens

\begin{tabular}{|c|c|c|c|c|c|c|}
\hline $\begin{array}{l}\text { Run } \\
\text { No. }\end{array}$ & $\begin{array}{l}\text { Welder } \\
\text { Setting } \\
\text { (amp) }\end{array}$ & $\begin{array}{c}\text { Actual } \\
\text { Current } \\
\text { (amp) }\end{array}$ & $\begin{array}{l}\text { EMF } \\
(v)\end{array}$ & $\begin{array}{l}\text { Power } \\
(\mathrm{w})\end{array}$ & $\begin{array}{l}\text { Time } \\
(\mathrm{sec})\end{array}$ & Broke \\
\hline 1438 & 100 & 108 & 26.0 & 2808 & 16.0 & No \\
\hline 1453 & 125 & 132 & 26.1 & 3445 & 15.0 & No \\
\hline 1454 & 125 & 133 & 26.1 & 3471 & 16.0 & No \\
\hline 1451 & 130 & 135 & 26.1 & 3526 & 16.0 & No \\
\hline 1441 & 135 & 140 & 25.2 & 3528 & 15.0 & No \\
\hline 1440 & 125 & 135 & 26.2 & 3537 & 15.0 & No \\
\hline 1450 & 130 & 135 & 26.2 & 3537 & 15.0 & No \\
\hline 1447 & 130 & 135 & 26.2 & 3537 & 15.0 & No \\
\hline 1452 & 130 & 135 & 26.2 & 3537 & 8.0 & Yes \\
\hline 1449 & 130 & 135 & 26.3 & 3550 & 15.0 & No \\
\hline 1448 & 130 & 135 & 26.3 & 3550 & 5.0 & Yes \\
\hline 1455 & 135 & 141 & 26.0 & 3666 & 16.0 & No \\
\hline 1442 & 140 & 145 & 25.8 & 3741 & 15.0 & No \\
\hline 1446 & 135 & 140 & 27.0 & 3780 & 3.5 & Yes \\
\hline 1456 & 140 & 145 & 26.1 & 3785 & 16.0 & No \\
\hline 1445 & 140 & 145 & 26.7 & 3872 & 6.0 & Yes \\
\hline 1443 & 145 & 148 & 26.7 & 3952 & 4.0 & Yes \\
\hline 1444 & 145 & 148 & 27.0 & 3996 & 6.0 & Yes \\
\hline 1457 & 145 & 153 & 26.2 & 4009 & 15.0 & No \\
\hline 1458 & 150 & 160 & 26.9 & 4304 & 15.5 & No \\
\hline 1462 & 150 & 160 & 26.9 & 4304 & 15.0 & No \\
\hline 1439 & 150 & 165 & 26.8 & 4422 & 4.0 & Yes \\
\hline 1463 & 155 & 165 & 26.9 & 4439 & 15.0 & No \\
\hline 1460 & 155 & 165 & 27.0 & 4455 & 3.5 & Yes \\
\hline 1461 & 155 & 173 & 25.9 & 4481 & 3.0 & Yes \\
\hline 1459 & 155 & 165 & 27.6 & 4554 & 5.0 & Yes \\
\hline 1464 & 160 & 173 & 27.0 & 4671 & 15.0 & No \\
\hline 1465 & 165 & 182 & 27.1 & 4932 & 15.0 & No \\
\hline 1466 & 170 & 185 & 27.9 & 5162 & 3.0 & Yes \\
\hline 1468 & 170 & 185 & 28.0 & 5180 & 15.0 & No \\
\hline 1467 & 170 & 185 & 28.9 & 5347 & 3.0 & Yes \\
\hline 1437 & 175 & 205 & 27.0 & 5535 & 3.0 & Yes \\
\hline 1471 & 175 & 200 & 27.7 & 5540 & 15.0 & No \\
\hline 1470 & 175 & 198 & 28.0 & 5544 & 5.0 & Yes \\
\hline 1469 & 175 & 199 & 27.9 & 5552 & 5.0 & Yes \\
\hline 1472 & 175 & 200 & 28.0 & 5600 & 5.0 & Yes \\
\hline 1436 & 225 & 255 & 27.0 & 6885 & 2.0 & Yes \\
\hline 1435 & 275 & 310 & 29.2 & 9052 & 2.0 & Yes \\
\hline
\end{tabular}



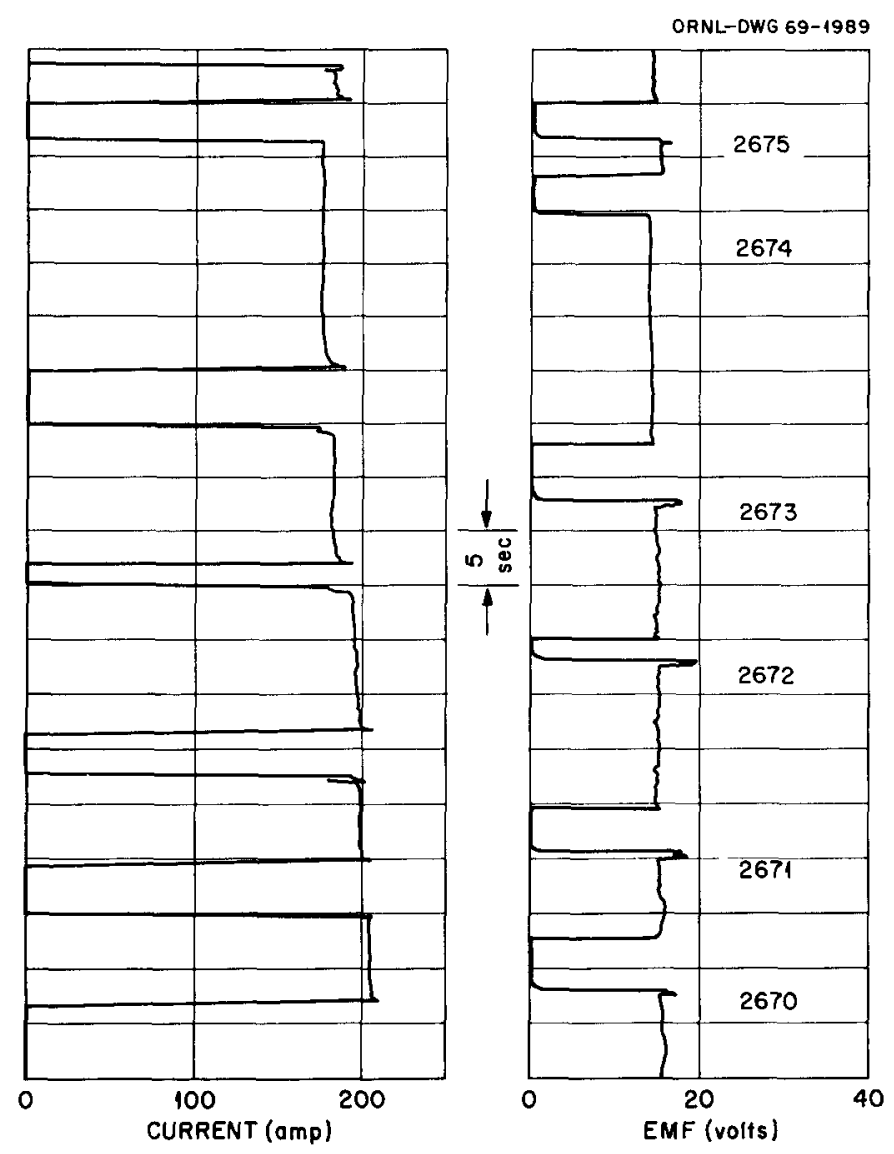

Fig. 4. Typical Brown Recorder Chart from Thermal Rupture Tests.

maintained. If fracture had not occurred after $15 \mathrm{sec}$, the test was terminated. The last column indicates whether the specimen fractured.

The first specimen tested, specimen 1435, was carefully positioned on the support plate with the steel ring on top of it, and the power supply to the welder, which in this instance was one of the Miller welders, was adjusted to $275 \mathrm{amp}$ and energized. The helium was turned on and adjusted to a flow rate of $50 \mathrm{cfh}$, and then the arc was initiated. After $2 \mathrm{sec}$ the specimen broke, and the arc was extinguished.

The distance from the electrode to the specimen was measured and, if necessary, reset. Specimen 1436 was then positioned on the test stand, and the welder setting was decreased to $225 \mathrm{amp}$. Again, the specimen failed approximately 2 sec after the arc was initiated. Consequently, the welder setting was reduced still more for specimen 1437, which failed 
after $3 \mathrm{sec}$. Specimen 1438 had not cracked 16 sec after the arc had been initiated so the arc was extinguished, and the specimen was discarded. The power region of interest was now known to be between 2808 and $5535 \mathrm{w}$. The next specimen was tested at a welder setting between the welder setting for the preceding specimen and the lowest welder setting that had broken a specimen. This procedure was continued, as shown in Table 1 , until it appeared that the region within which some specimens would break and others would not had been determined for PO3 graphite. The specimens that did not break were not retested, since the high temperatures involved had undoubtedly changed the material in the disk. Also, the power level for each specimen was held constant as shown in Fig. 4. The lowest power at which a 2-in.-diam P03 specimen failed was $3537 \mathrm{w}$, and the highest power at which a specimen did not fail was $5540 \mathrm{w}$.

Method for Determining Threshold Power Level for Thermal Rupture

The "staircase method"18 for determining the fatigue strength of metals was adaptable to determining the threshold power level for thermal rupture. The mechanics of this method are indicated in Table 2 for the data listed in Table 1 . First, a power increment, $d$, analogous to the stress increment in fatigue testing, is selected. A power increment of $0.6 \mathrm{kw}$ was used in this instance. The number of specimens that broke within each power increment, $\mathrm{N}_{\mathrm{X}}$, and the number that did not break, $\mathrm{N}_{0}$, are then listed. Data taken prior to the first pair that gave opposite results were not used. The total number of specimens that failed is compared with the total that did not fail. Only data from the less frequent event is used in the subsequent analysis - failures in this case. The power levels are then numbered sequentially, starting with zero assigned to the lowest power level at which the less frequent event occurred, $\mathrm{P}_{\circ}$. The power level number is then multiplied by the number of less frequent events which occurred at that power level, and the products are summed. The sum is denoted by $A$ in the equation below. The threshold power level, $P$, is then determined from the formula

$$
P=P_{0}+d\left(\frac{A}{N} \pm \frac{1}{2}\right)
$$


Table 2. Staircase Method for Determining Threshold Power for Thermal Rupture of Graphite Disks

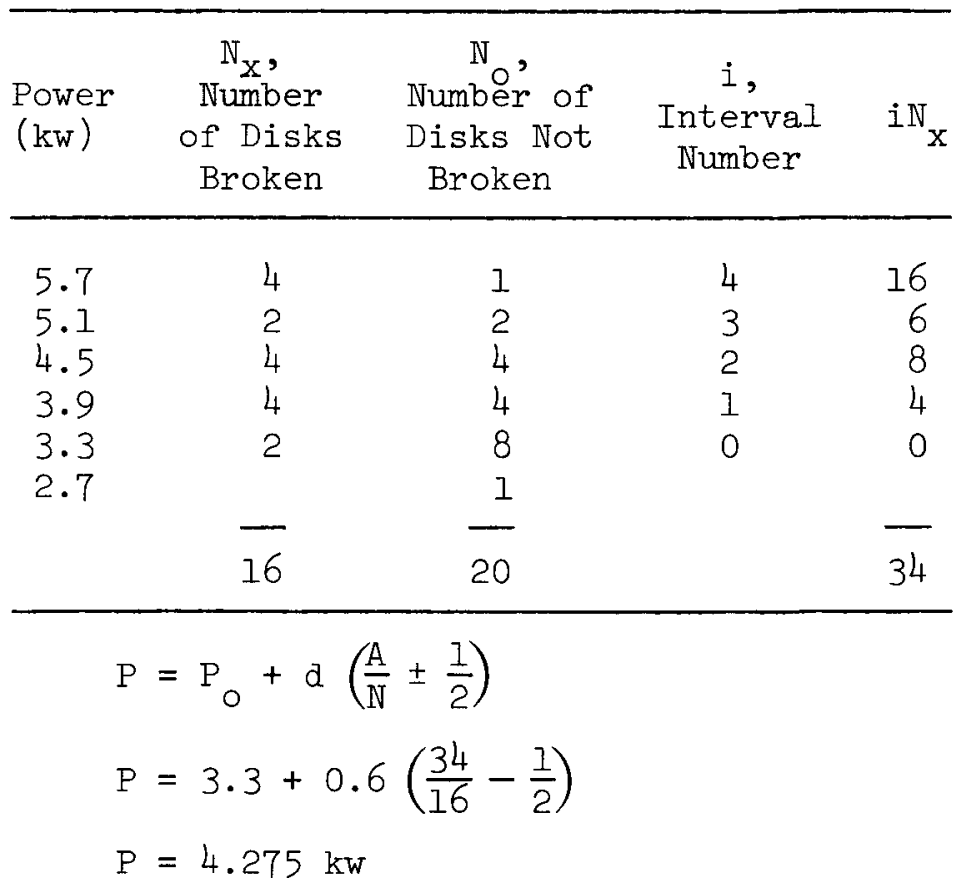

where $N$ is the number of less frequent events, and the other symbols are as defined previously. Plus $1 / 2$ is used if the less frequent event is "not broken," and $-I / 2$ is used if the less frequent event is "broken." The threshold power for 2-in.-diam P03 graphite specimens is $4.3 \mathrm{kw}$. The higher the threshold power, the more thermal stress resistant the material is.

Examination of Fractured Specimens

Typical broken specimens are shown in Fig. 5. The AGOT specimens did not crack completely, whereas the RVD specimens broke into two or more pieces. The AGOT specimens were the only ones that did not consistently break completely; all other types of graphite failed in the catastrophic manner exhibited by the RVD specimens. All the specimens shown in Fig. 5, except the 3/4-in.-diam AGOT specimen, were heated on the side opposite the one that can be seen in the photograph. The slightly lighter 

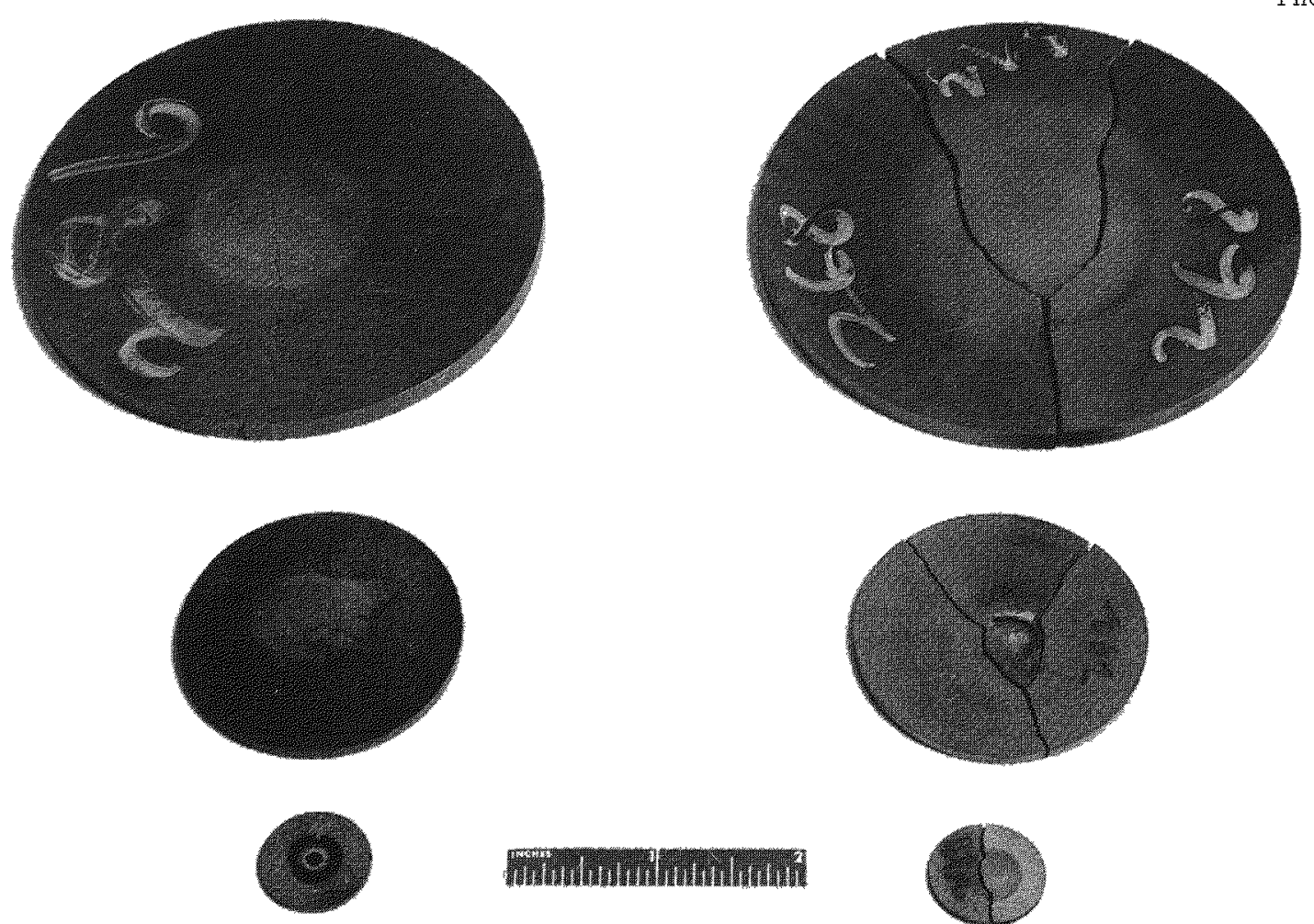

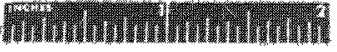

AGOT

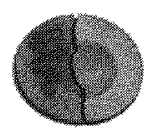

RVD

Fig. 5. Broken Thermal Shock Specimens.

spot at the center of the disks was caused by the high temperature during the test.

When specimens were heated at high power levels for several seconds, a spherical cavity was formed where the arc struck the specimen. The depth of the crater increased as the power and time increased. When very low power was used, or when the specimen broke very quickly, no craters were produced. The craters were usually covered with metal which was apparently transferred from the electrode. The craters probably developed because graphite sublimed. Holes were produced in some of the 3/4-in.diam specimens tested at high power levels. Valid measurements of the thermal shock resistance of several graphites could not be made using 3/4-in.-diam specimens because holes were produced before fracture could occur. The hole interrupted the test because it destroyed the vacuum that held the specimen in position. 


\section{Test Results and Analysis}

The relative thermal stress resistances of 21 different types of graphite were determined, and many of the types were tested in all three specimen sizes. The results are listed in Table 3. Two sets of data are given for ATJ, 2033, and SX5 graphite. The ATJ and SX5 specimens supplied by Lyon of Los Alamos Scientific Laboratory were heat treated to $2500^{\circ} \mathrm{C}$ in helium for $1 \mathrm{hr}$. The first shipment of 2033 graphite was baked by an accelerated process. The other 2033 material was baked in the usual way. The threshold power and power ranges are given in Table 3, with the threshold power being the power above which a specimen is likely to fail. The range gives the lowest power at which a specimen cracked to the highest power at which a specimen did not break. Below the lower limit of the range, no failures were observed; within the range, some specimens broke and some did not. All specimens tested at power levels above the range cracked.

The threshold power is plotted versus specimen diameter in Fig. 6 to illustrate that results agree for different specimen sizes. Although the data from 2- and 4-in.-diam specimens show excellent agreement, the data from 3/4-in.-diam specimens do not quite agree. The curves of Fig. 6 fall into three broad groups. The ZTA, ATJ, and Graphitite G specimens are extremely resistant to thermal shock. The RVD, RVA, 780-S, P03, H205, and 2033 specimens fall into a group of intermediate thermal shock resistance and the SX5, AGOT, and British isotropic types comprise the group with the lowest thermal shock resistance. The tests on 3/4-in.-diam specimens correctly place these graphites in the proper group, but relative ranking of the graphites in the intermediate group does not always agree with that obtained with larger specimens. Since the graphites in the group that has the best thermal shock resistance cannot be broken in the 4-in.-diam specimen size with the power supply available, the most useful specimen size is the 2-in.-diam specimen.

A bar graph of the results of the thermal rupture tests on 2-in.-diam specimens is given in Fig. 7. The dotted portion of the bars extends to the lowest power at which fracture was obtained. The crosshatched portion ranges from the lowest power at which a fracture occurred to the highest 
Table 3. Relative Thermal Shock Resistance of Graphite

\begin{tabular}{|c|c|c|c|c|c|c|}
\hline \multirow{3}{*}{ Grade } & \multicolumn{6}{|c|}{ Power Necessary to Produce Fracture (kw) } \\
\hline & \multicolumn{2}{|c|}{ 3/4-in.-diam Specimens } & \multicolumn{2}{|c|}{ 2-in.-diam Specimens } & \multicolumn{2}{|c|}{ 4-in.-diam Specimens } \\
\hline & Threshold & Range & Threshold & Range & Threshold & Range \\
\hline ZTA & 5.50 & $5.30-5.89$ & 20.0 & $19.99-19.90$ & $>20.5$ & (a) \\
\hline$A T J^{b}$ & 5.10 & $4.65-5.27$ & 13.5 & $12.42-13.51$ & $>20.5$ & (a) \\
\hline ATJ & 3.00 & $2.28-2.91$ & 14.0 & $10.23-15.42$ & $>20.5$ & (a) \\
\hline RVA & 1.35 & $1.26-1.46$ & 7.3 & $6.67-7.98$ & $>20.5$ & (a) \\
\hline RVD & 1.30 & $1.09-1.50$ & 7.4 & $5.90-8.10$ & $24.0^{c}$ & $23.78-(c)$ \\
\hline AGOT & 0.40 & $0.37-0.40$ & 2.2 & $1.91-2.95$ & 5.8 & $5.72-7.40$ \\
\hline$A X F-5 Q$ & & & 7.7 & $5.70-10.54$ & & \\
\hline AXZ-9Q & & & 11.5 & $9.94-11.69$ & & \\
\hline AXM-9Q & & & 10.5 & $9.92-10.66$ & & \\
\hline$A X F-9 Q$ & & & 12.5 & $10.88-15.94$ & & \\
\hline $\mathrm{AXM}$ & & & 14.0 & $11.56-15.16$ & & \\
\hline BXZ-9Q & & & 3.8 & $3.11-4.19$ & & \\
\hline $2033^{d}$ & 1.50 & (a) & & & & \\
\hline 2033 & 0.95 & $0.94-1.03$ & 6.6 & $6.17-7.40$ & 21.0 & $19.48-20.81$ \\
\hline PO3 & 1.40 & $1.41-1.38$ & 4.3 & $3.54-5.54$ & 15.0 & $14.43-17.51$ \\
\hline $780 \mathrm{~S}$ & 1.45 & $1.32-1.62$ & 5.2 & $3.10-5.36$ & 21.0 & $21.11-21.00$ \\
\hline $\mathrm{sx} 5^{\mathrm{b}}$ & 0.55 & $0.53-0.60$ & 2.5 & $2.10-2.84$ & 13.0 & $11.72-13.96$ \\
\hline SX5 & 0.75 & $0.60-0.80$ & 2.8 & $2.28-3.20$ & 9.7 & $9.53-9.77$ \\
\hline 9326 & & & 5.0 & $3.84-5.70$ & & \\
\hline $\mathrm{H} 205$ & 0.90 & $0.80-0.95$ & 4.5 & $4.43-4.82$ & 17.5 & $16.27-18.24$ \\
\hline British isotropic & 0.38 & $0.36-0.50$ & 2.0 & $1.80-2.28$ & 5.0 & $4.62-5.33$ \\
\hline G5 & & & 9.0 & $4.91-11.70$ & & \\
\hline Graphitite G & 2.50 & $1.56-3.00$ & 11.0 & $7.35-12.96$ & $>20.5$ & (a) \\
\hline $\mathrm{W}$ & & & & & 3.5 & $3.10-4.20$ \\
\hline
\end{tabular}

a Range was not determined.

${ }^{\mathrm{b}}$ Supplied by L. L. Lyon, Los Alamos Scientific Laboratory.

Conly four specimens could be broken. The upper limit of the range was beyond the capacity of the welder. The threshold is somewhat higher than the value given.

dProduced by accelerated process. 


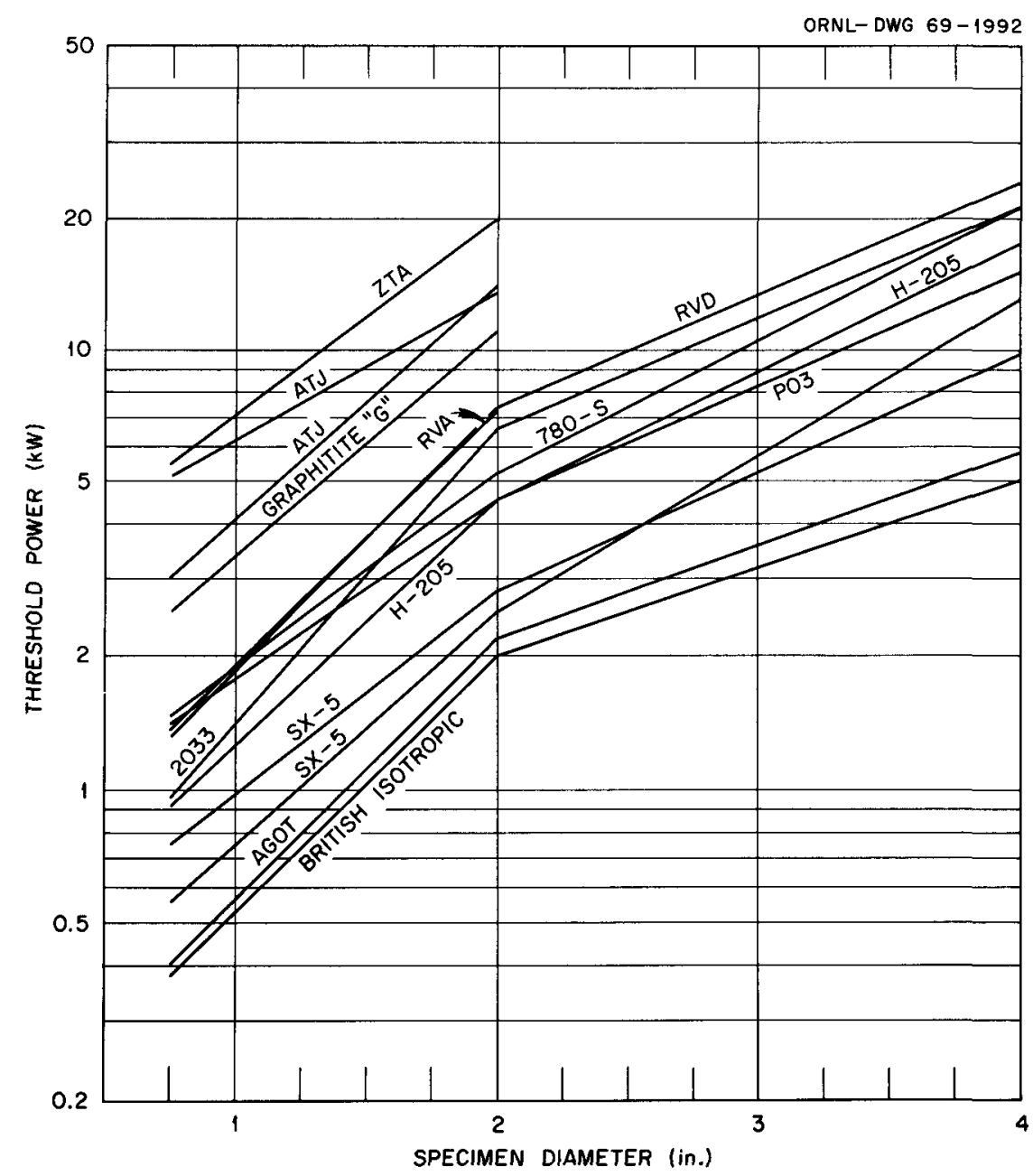

Fig. 6. Thermal Shock Resistance of Graphite Specimens of Three Sizes.

power at which a specimen did not break. The graphites are grouped according to the manufacturer. Although ZTA graphite appears to be the best graphite, it must be remembered that the plane of the disk corresponds with the plane of isotropy of the graphite. Thus, the with-grain direction of the molded graphites was tested, and the across-grain direction of the extruded graphites was tested.

Derby $^{3}$ has done a detailed analysis of the graphite disk heated at the center by a welder that is of help in understanding the basis of this test. The first step in a thermal stress analysis is the determination of the temperature distribution in the object of interest. Derby assumed 


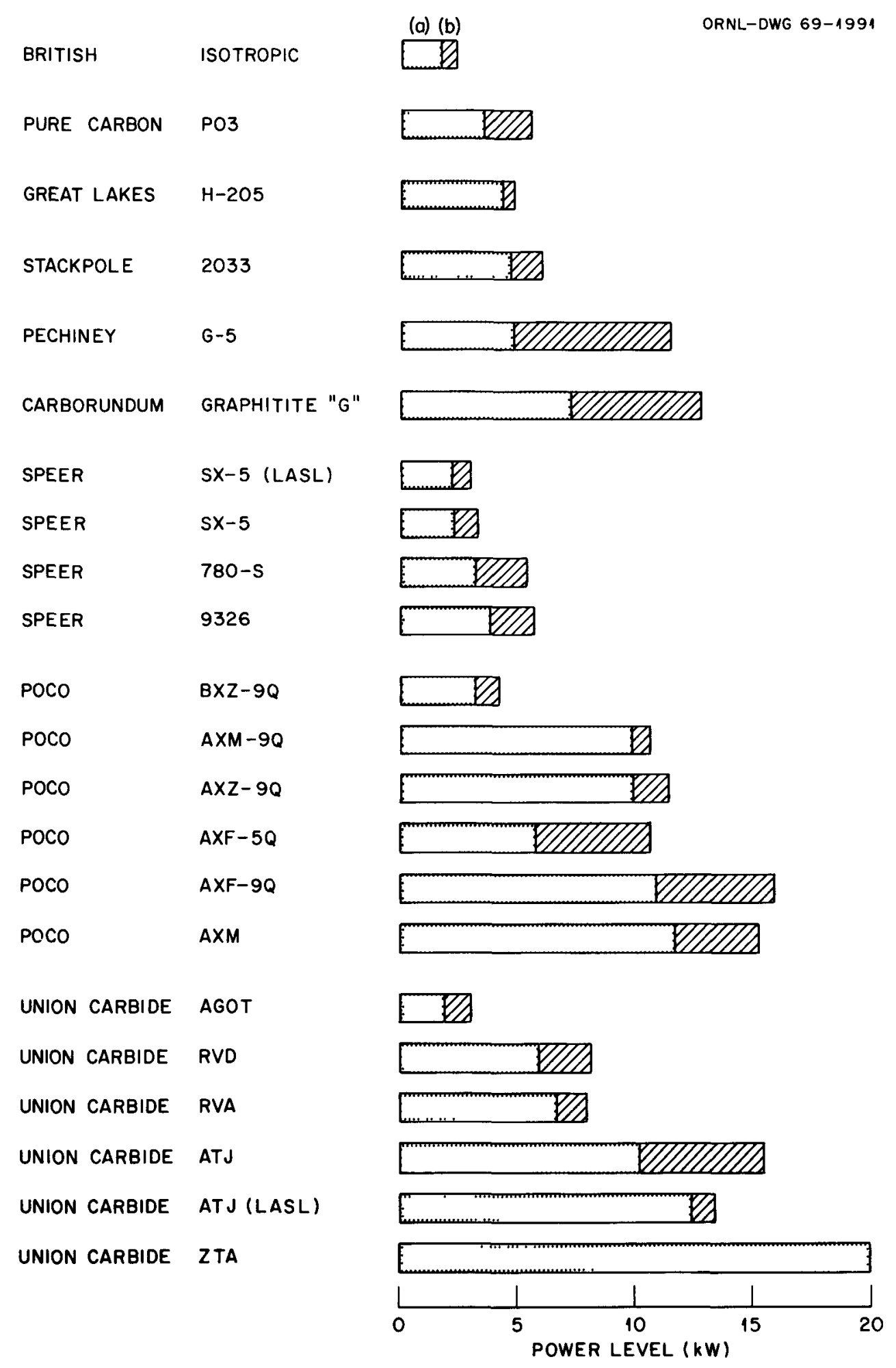

Fig. 7. Thermal Rupture Resistance of 2-in.-diam Graphite Specimens. (a) Lowest power at which fracture occurred. (b) Highest power at which a specimen did not break. 
that the temperature of the disk did not vary circumferentially or through the thickness of the disk. He used a finite-element axisymmetric heat transfer analysis that enabled him to take the temperature dependence of the thermal properties into account. Heat was introduced into the disk near the center in a manner that approximated the heat input from the arc. In addition, inside a radius of $0.02 \mathrm{in}$. the disk was assumed to be at the sublimation temperature from the start of the test. The temperature distributions calculated for three different power levels after 10 sec are shown in Fig. 8. These distributions are in reasonable agreement with unrefined measurements made with thermocouples.

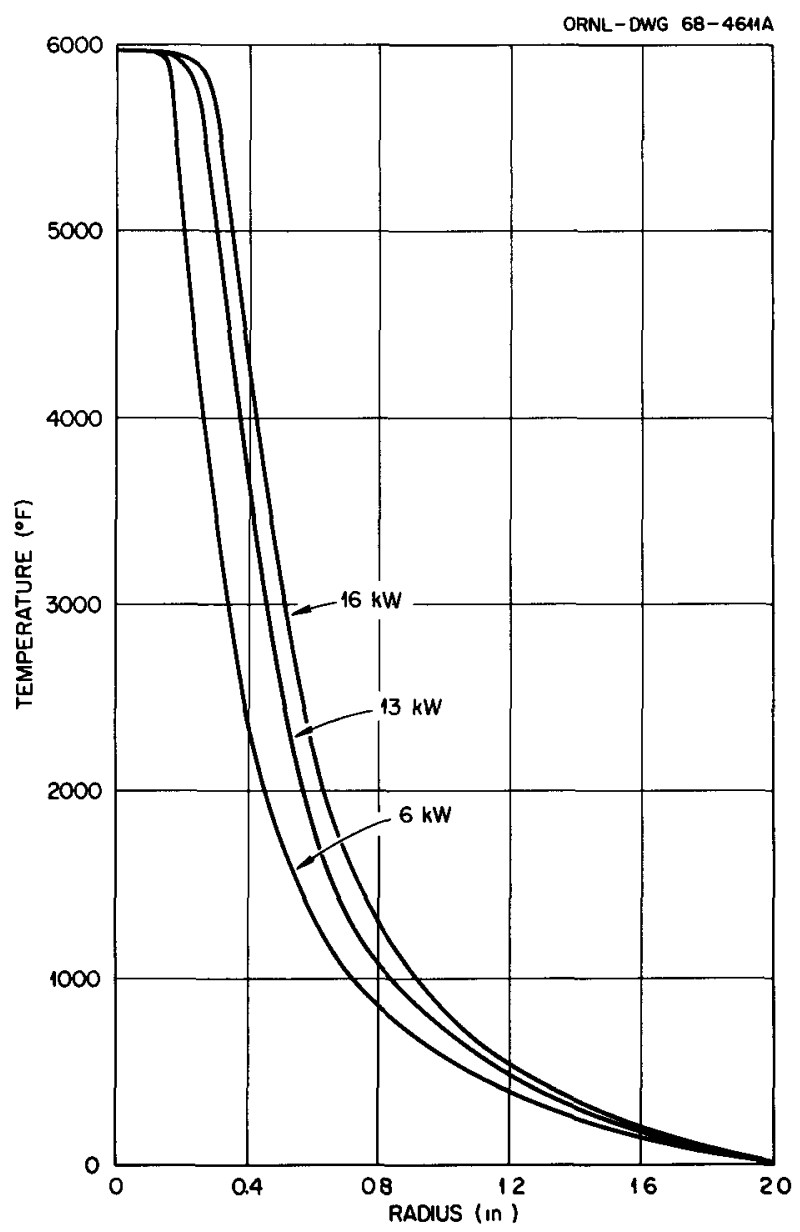

Fig. 8. Temperature Distributions in RVD Specimen After $10 \mathrm{sec}$ at Three Power Inputs. 
As indicated in the Appendix the modulus of elasticity and coefficient of thermal expansion both vary with temperature. Also the stressstrain curves for graphite are nonlinear. Derby was able to take both these factors into account by using finite-element techniques, with the effect shown in Table 4, where the maximum ratios of tensile stress to tensile fracture strength obtained with the different assumptions of material behavior are tabulated for RVD graphite at two power levels and for ATJ graphite at one power level. The most realistic analysis is the plastic analysis with variable modulus, which takes into account both the nonlinearity of the stress-strain curve and the variation of properties with temperature. The ratio of tensile stress to tensile strength is from 41 to $66 \%$ higher when the elastic analysis with a constant value for modulus of elasticity is used than when the plastic analysis with variable modulus is used. The analyses that only add the consideration of the plasticity or variation of modulus with temperature give ratios of tensile stress to tensile strength that are between those given by the elastic analysis with a constant value for modulus of elasticity and the plastic analysis with variable modulus of elasticity.

Table 4. Maximum Ratio of Tensile Stress to Tensile Strength in 4-in.-diam Specimens

\begin{tabular}{lcccc}
\hline & $\begin{array}{l}\text { Plastic } \\
\text { Analysis } \\
\text { Variable } \\
\text { Modulus }\end{array}$ & $\begin{array}{l}\text { Plastic } \\
\text { Analysis } \\
\text { Constant } \\
\text { Modulus }\end{array}$ & $\begin{array}{l}\text { Elastic } \\
\text { Analysis } \\
\text { Variable } \\
\text { Modulus }\end{array}$ & $\begin{array}{l}\text { Elastic } \\
\text { Analysis } \\
\text { Constant } \\
\text { Modulus }\end{array}$ \\
\hline RVD at $25 \mathrm{kw}$ & 0.89 & 1.07 & 1.02 & 1.35 \\
RVD at $33 \mathrm{kw}$ & 1.09 & 1.25 & 1.26 & 1.54 \\
ATJ at $33 \mathrm{kw}$ & 0.64 & 0.87 & 0.67 & 1.06 \\
\hline
\end{tabular}

The radial stress is always compressive. Examination of fractured specimens indicates that fracture is caused by tangential tensile stress. The tangential stress distributions in RVD graphite at two power levels determined by the plasticity analysis are shown in Fig. 9. The stress 


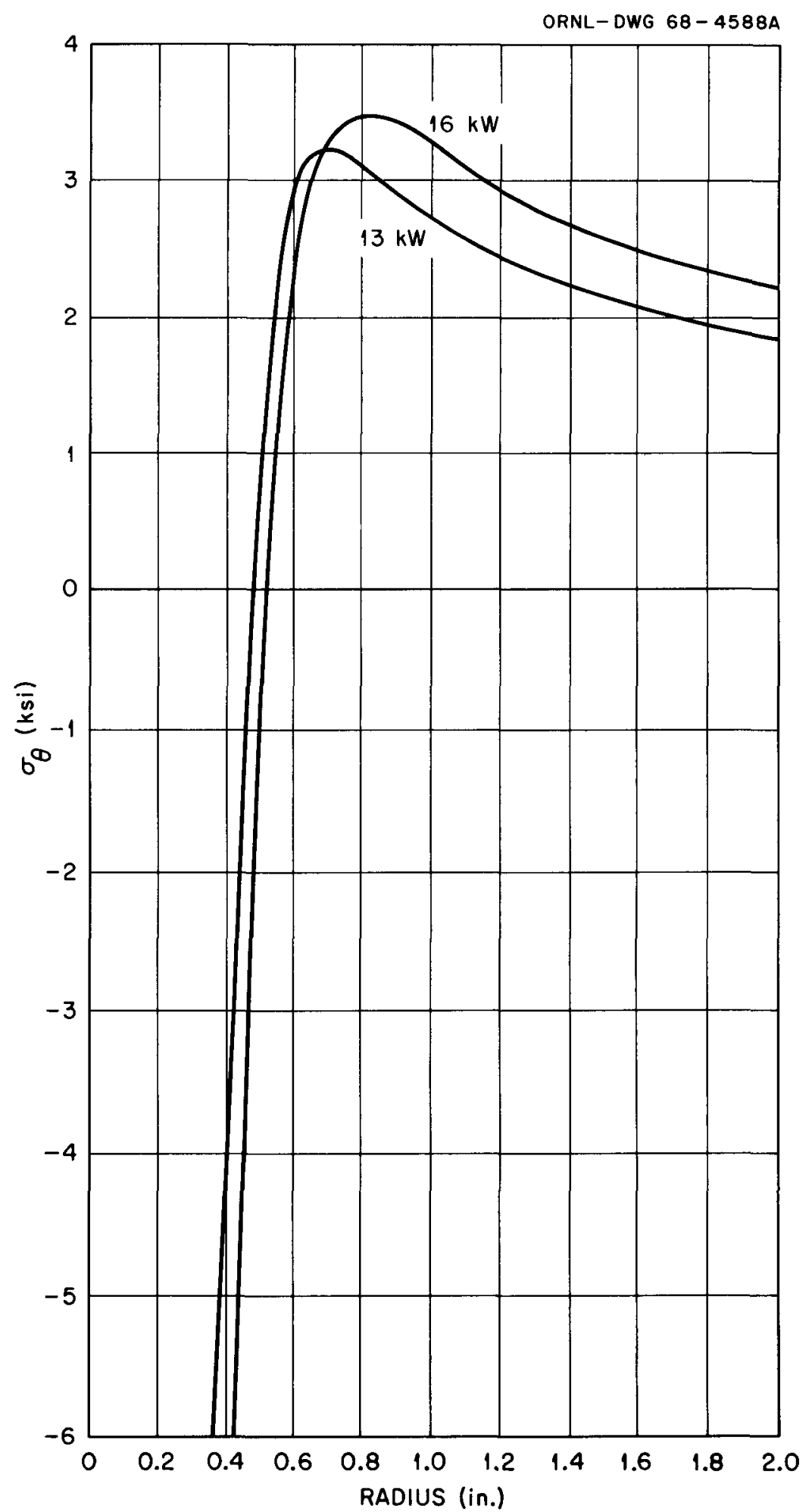

Fig. 9. Tangential Stress Distributions in RVD Specimen After 10 sec at Two Power Inputs. 
near the center is compressive and is of considerable magnitude. It is tensile in the outer region of the disk. The maximum stress is not at the edge of the disk and is different for the two power levels. This figure shows that there is a direct correspondence between welder power and the maximum tensile stress in the disk.

The stresses in 4-in.-diam disks of AGOT, P03, H205, RVD, AXF-5Q, and ATJ graphite were calculated at power levels of $6,13,16,25,33$, and $37 \mathrm{kw}$. The analysis indicated that AGOT graphite was the only one that would fail at a power level of $6 \mathrm{kw}$, and the measured threshold power level for AGOT was $5.8 \mathrm{kw}$. The calculations for $13 \mathrm{kw}$ indicated that P03 disks should fail; however, the measured threshold power was $16 \mathrm{kw}$. The analysis indicated that $\mathrm{H} 205$ graphite disks would fracture at a power level of $16 \mathrm{kw}$, and the threshold power for the 4-in.-diam H205 disks was $17.5 \mathrm{kw}$. Fracture of the RVD graphite was not predicted by the analysis below a power level of $33 \mathrm{kw}$. Since the next lower power analyzed was $25 \mathrm{kw}$ and only a few 4-in.-diam RVD specimens could be broken at $24 \mathrm{kw}$, this result is in agreement with the test results. No 4-in.diam disks of AXF-5Q were tested, and 4-in.-diam specimens of ATJ could not be broken with the available equipment. The analysis indicated that more than $37 \mathrm{kw}$ would be required to break both these graphites. The predictions of the analysis are thus in reasonable agreement with the measured threshold power levels.

\section{Comparison With Figures of Merit}

Thermal stress analyses are usually done by assuming that the material is elastic and homogeneous and that properties do not vary with temperature. After a few such analyses, it is discovered that while both the geometry of the component and properties of the material determine the stresses in the component, they may be considered more or less independently; that is, the stresses are equal to a constant which is dependent on the material properties multiplied by a function of the geometry of the component. For example, the stresses in a thick-walled cylinder with steady-state radial heat flow are given by Timoshenko ${ }^{17}$ as 


$$
\begin{gathered}
\sigma_{r}=\frac{T_{i}}{2} \frac{\alpha E}{1-\nu \log \frac{b}{a}}\left[-\log \frac{b}{r}-\frac{a^{2}}{b^{2}-a^{2}}\left(1-\frac{b^{2}}{r^{2}}\right) \log \frac{b}{a}\right], \\
\sigma_{\theta}=\frac{T_{i}}{2} \frac{\alpha E}{1-v} \frac{1}{\log \frac{b}{a}}\left[1-\log \frac{b}{r}-\frac{a^{2}}{b^{2}-a^{2}}\left(1-\frac{b^{2}}{r^{2}}\right) \log \frac{b}{a}\right], \\
\sigma_{z}=\frac{T_{i}}{2} \frac{\alpha E}{l-v} \frac{1}{\log \frac{b}{a}}\left(1-2 \log \frac{b}{r}-\frac{2 a^{2}}{b^{2}-a^{2}} \log \frac{b}{a}\right),
\end{gathered}
$$

where

$$
\begin{aligned}
\sigma_{r}, \sigma_{\theta}, \sigma_{z}= & \text { radial, circumferential, and axial stress, respectively, } \\
\mathrm{T}_{i}= & \text { difference in the temperature of the inside wall of the } \\
& \text { tube and the outside wall, } \\
\alpha= & \text { coefficient of thermal expansion, } \\
E= & \text { modulus of elasticity, } \\
\nu= & \text { Poisson's ratio, } \\
a= & \text { inside radius of the cylinder, } \\
\mathrm{b}= & \text { outside radius, } \\
\mathrm{r}= & \text { radius at which stress is being calculated. }
\end{aligned}
$$

Note that the expression for each stress includes a temperature difference term $\mathrm{T}_{i} / 2$, a material property term, $\alpha \mathrm{E} /(1-v)$, and a geometry term that is a function of $b, a$, and $r$ only.

Thermoelastic analyses indicate three figures of merit for rating the thermal stress resistance of brittle materials. ${ }^{6}$ They are

$$
\begin{aligned}
& \frac{\sigma_{f}(1-v)}{E \alpha}, \\
& \frac{k \sigma_{f}(1-v)}{},
\end{aligned}
$$


and

$$
\frac{k \sigma_{f}(I-v)}{\rho c_{p}^{E \alpha}},
$$

where $\sigma_{f}$ is the fracture strength, $\nu$ is Poisson's ratio, E is modulus of elasticity, $\alpha$ is the coefficient of thermal expansion, $k$ is the thermal conductivity, $\rho$ is the density, and $c_{p}$ is the specific heat. Since Poisson's ratio for graphite is small, it can be neglected. The specific heats of all graphites are essentially the same, as were the densities of all graphites tested, so the third figure of merit need not be considered. The figures of merit, $\sigma_{f} / E \alpha$ and $k \sigma_{f} / E \alpha$, are plotted versus the threshold power level for 11 different graphites in Figs. 10 and 11 . The threshold power levels are for the 2-in.-diam disks. The property values were obtained from the Appendix. The thermal conductivity values were measured

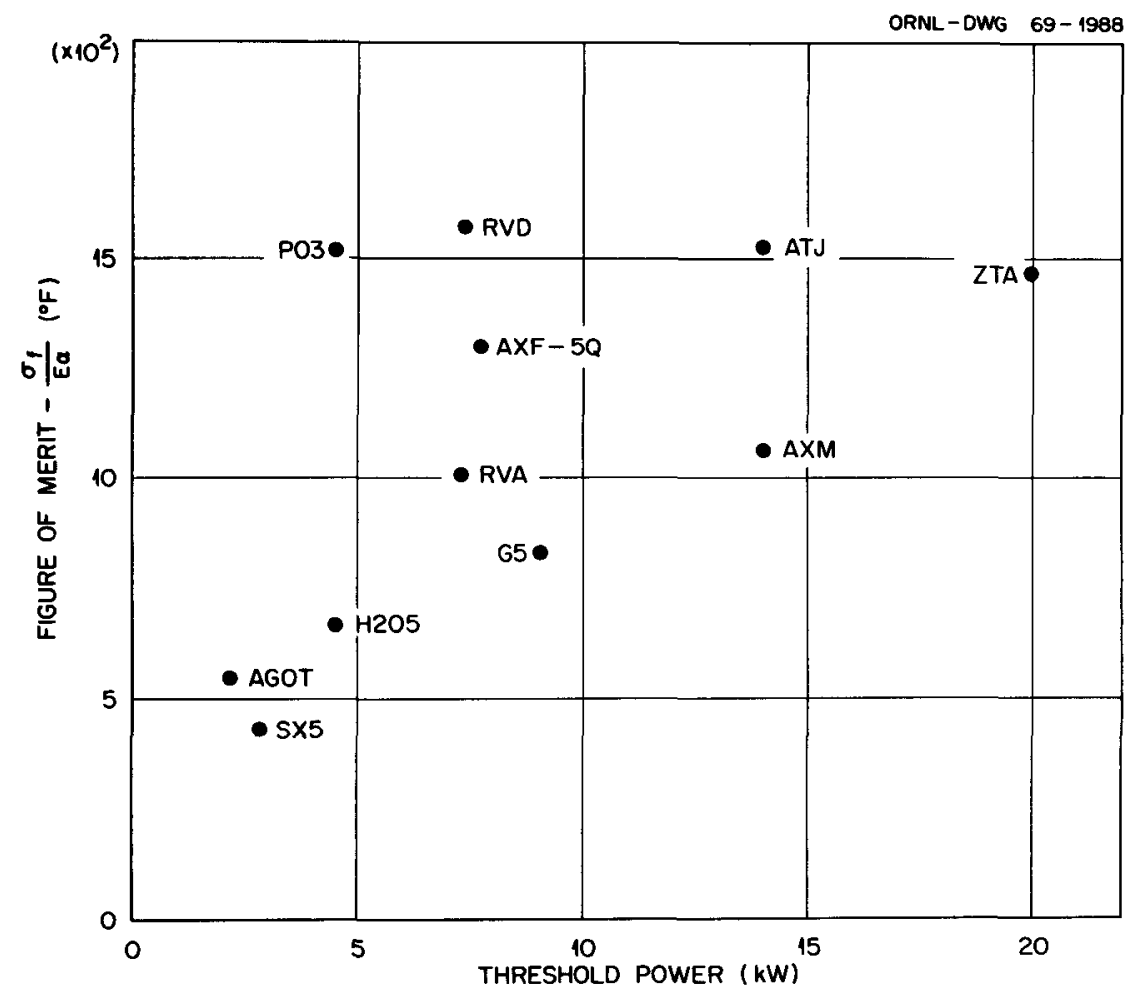

Fig. 10. Figure of Merit, $\sigma_{f} / E \alpha$, Versus Threshold Power. 


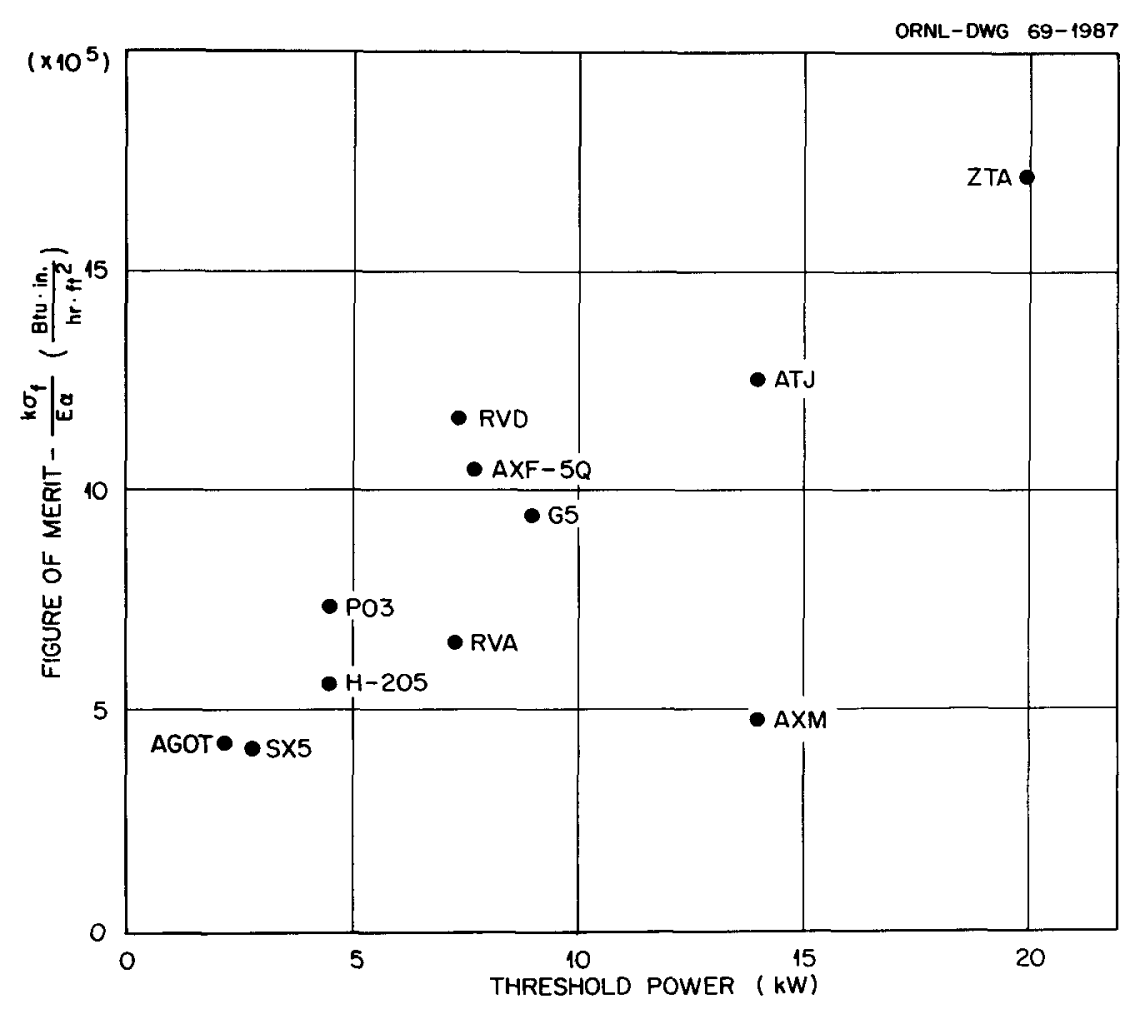

Fig. 11. Figure of Merit, $k \sigma_{f} / E \alpha$, Versus Threshold Power.

at $250^{\circ} \mathrm{F}$. Room-temperature strength and modulus values were used, and the coefficient of thermal expansion was the mean thermal expansion from room temperature to $2000^{\circ} \mathrm{F}$. The primary reason for selecting data at these temperatures was availability. The temperature at which the properties are measured affects the thermal stress rating of the graphites, as was demonstrated recently by D'Amelio and Roetling. " The property values were measured in engineering units so that the dimension of $\sigma_{f} / E \alpha$ is ${ }^{\circ} \mathrm{F}$ and the dimension of $k \sigma_{f} / E \alpha$ is $B t u \cdot i n . / h r \cdot f t^{2}$.

Figures 10 and 11 show that neither of the figures of merit correlate well with the thermal shock test results. Had the figure of merit $\sigma_{f} / E \alpha$ been used to select a graphite for an application which duplicated the test conditions, P03, AXF-5Q, and AXM graphites would have been considered the best materials. However, ZTA graphite was found to be the most thermal shock resistant in the test and was far superior to $\mathrm{PO} 3$ graphite. The second figure of merit correctly ranks ZTA graphite as the most thermal-shock- 
resistant material. The two next best graphites, ATJ and AXM, had the same thermal shock resistance, but the figure of merit $k \sigma_{f} / E \alpha$ rates $A X M$ graphite as much less thermal shock resistant than ATJ graphite.

Because of the differences in tensile properties reported by different persons, as discussed in the Appendix, special attention should be paid to ZTA, ATJ, and RVD graphites. The values of strength and modulus used to determine the figures of merit were all obtained from Seldin's data, ${ }^{19}$ and the values of thermal expansion were all measured by Thornburgh and Pyron. 20 Figure 10 shows that the relative thermal shock resistances predicted for these three materials were not at all the same as their relative ranking from the test.

According to Kingery, ${ }^{6}$ the figure of merit $\sigma_{f} / E \alpha$ is applicable to high rates of heat transfer, whereas $k \sigma_{f} / E \alpha$ is applicable to low rates of heat transfer. It appears that the figure of merit $\sigma_{f} / E \alpha$ should have correlated better with the test results than $k \sigma_{f} / E \alpha$, since the rate of heat transfer is extremely high in the thermal shock test. Derby ${ }^{3}$ found that the value of thermal conductivity used had little effect on the calculated temperature distribution.

\section{Conclusions}

A simple test has been developed for ranking graphites according to their thermal shock resistance. The necessary equipment is easily obtainable, and the specimen geometry is simple. Although approximately 30 specimens of each graphite must be tested, the time required for each test is so short that several graphites can be ranked in a short time. Because of the empirical nature of the test, all graphites must be tested under identical conditions for the rankings to be valid.

The most thermal-shock-resistant graphite tested was ZTA graphite, which was also the most anisotropic material tested. Since the specimens were all oriented so that the plane of the disk corresponded to the plane of isotropy, the ability of ZTA graphite to withstand thermal gradients in the across-grain direction is unknown. AXM and AXF-9Q graphites, which are apparently isotropic, exhibited good thermal shock 
resistance. In addition, these two graphites have extremely high coefficients of thermal expansion.

The rankings of 11 grades of graphite determined by figures of merit did not correlate well with their rankings obtained from the test. These results indicate that the figures of merit, $\sigma_{f} / E \alpha$ and $k \sigma_{f} / E \alpha$, should not be used in the selection of thermal-stress-resistant graphites. The thermal shock test described here should be used as a tool for screening graphites for applications where the thermal environment is similar to that of the test specimen. For conditions that are different, some other suitable test should be developed for screening candidate materials.

The thermal shock test described here is useful for determining the most thermal-shock-resistant materials. For critical applications, thermal and mechanical properties of the graphites selected with the test must be determined so that the final selection can be made on the basis of detailed realistic analyses that consider the conditions that will be experienced by the component. As an alternative, components of the selected graphites should be tested under design conditions. The chief application of this test method should be to limit the number of graphites that must be thoroughly investigated for a particular application. 


\section{$\underline{\text { References }}$}

1. A. J. Kennedy, The Materials Background to Space T'echnology, George Newnes, Ltd., London, 1964.

2. W. V. Goeddel and J. N. Siltanen, Materials for High-Temperature Nuclear Reactors, Annual Review of Nuclear Science, p. 189, edited by E. Serge, G. Friedlander, and H. P. Noyes, Annual Reviews, Inc., Palo Alto, Calif., 1967.

3. R. W. Derby, Thermal Shock of Graphite Disks, Doctor of Science dissertation, Colorado School of Mines, Golden, Colorado, June 1968.

4. V. J. D'Amelio and J.A. Roetling, Extreme Temperature Performance of Graphites, AIAA Paper No. 68-297, American Institute of Aeronautics and Astronautics, New York, April 1968.

5. E. G. Kendall and J. D. McClelland, Nonmetallic Materials for HighTemperature Structural Applications, Symposium on Newer Structural Materials for Aerospace Vehicles, ASTM Special Technical Publication No. 379, p. 77, American Society for Testing and Materials, Philadelphia, 1965.

6. W. D. Kingery, Property Measurements at High Temperatures, pp. 201214, Wiley, New York, 1959.

7. E. Glenny and M. G. Royston, Transient Thermal Stresses Promoted by the Rapid Heating and Cooling of Brittle Circular Cylinders, Trans. Brit. Ceramic Soc., 57:645-676 (1958).

8. W. M. Wells and C. F. Cline, Thermal-Stress Fracture Characteristics of BeO, ASME Paper 63-WA-297, American Society of Mechanical Engineers, New York, 1963.

9. A. Arias, Investigation of Thermal Shock Resistance of Zirconia with Metal Additions, NASA Technical Note NASA TN D-2464, National Aeronautics and Space Administration, September 1964.

10. A. R. Crocker, Thermal Stress Tests of KS Graphite, USAEC Report NEPA-1125-EXR-2, Fairchild Engine and Airplane Corp., 1949.

11. A. R. Crocker, Thermal Stress Tests on 5\% Uranium Impregnated Graphite, USAEC Report NEPA-1369-EXR-7, Fairchild Engine and Airplane Corp., 1949.

12. W. B. Powell and P. E. Massier, Heat-Flux-Rupture Limits with Internal Heat Generation of Several Graphites Up to $5000^{\circ} \mathrm{F}$, Proceedings of 3rd Conference on Carbon, pp. 543-557, Pergamon Press, New York, June 1957. 
13. J. M. Corum and F. T. Dodge, Graphite Thermal Rupture Studies, pp. 3135, Gas-Cooled Reactor Program Quarterly Progress Report for Period Ending Sept. 30, 1961, USAEC Report ORNL-3210, Oak Ridge National Laboratory .

14. E. S. Bomar et al., Evaluation of Graphite-Matrix Fuel Elements, pp. 308-311, Gas-Cooled Reactor Program Semiannual Progress Report for Period Ending Sept. 30, 1963, USAEC Report ORNL-3523, Oak Ridge National Laboratory.

15. J. R. Bohn and K. R. King, An Investigation of the Thermal Shock Behavior of Refractory Materials, Report AFML-TR-65-393, TWR Systems, December 1965.

16. J. R. Bohn, K. R. King, C. H. Ernest, and K. R. Janowski, NonsteadyState Thermal Stress Behavior of Refractory Materials, Report AFMLTR-67-315, TWR Systems, November 1967.

17. S. Timoshenko and J. N. Goodier, Theory of Elasticity, pp. 406-413, 2nd ed., McGraw-Hill, New York, 1951.

18. ASTM Committee E-9 on Fatigue, A Guide for Fatigue Testing and the Statistical Analysis of Fatigue Data, ASTM Special Technical Publication No. 91-A, 2nd ed., American Society for Testing and Materials, Philadelphia, 1963.

19. E. J. Seldin, Stress-Strain Properties of Polycrystalline Graphite in Tension and Compression at Room Temperature, Carbon, 4(2): 177191 (July 1966).

20. J. D. Thornburgh and C. M. Pyron, Jr., The Thermal Expansions of Ten Graphites to $5500^{\circ} \mathrm{F}$, Final Report to Union Carbide Corporation, Nuclear Division, by Southern Research Institute, Aug. 2, 1966.

21. F. J. Digesu and C. D. Pears, Some Parameters of the Mechanical Behavior of Graphites, a paper presented at the American Ceramic Society Meeting, Los Angeles, California, Southern Research Institute, Birmingham, Alabama, October 1963.

22. Tentative Methods of Tension Testing of Carbon-Graphite Mechanical Materials, ASTM Designation: C565-65T, 1968 Book of ASTM Standards, Part 13, American Society for Testing and Materials, Philadelphia, 1968.

23. B. L. Greenstreet et al., Room Temperature Mechanical Properties of EGCR-Type AGOT Graphite, USAEC Report ORNL-3728, Oak Ridge National Laboratory, January 1965.

24. S. L. Hoff, Airco Speer Graphite Handbook, Speer Carbon Company, St. Marys, Pennsylvania, 1967. 
25. C. L. Mantell, Carbon and Graphite Handbook, Interscience, New York, 1968.

26. J. Glasser and W. J. Glasser, Directory of Graphite Availability, Second Edition, Technical Report AFML-TR-67-113, TWR Systems, August 1967 .

27. G. Kamoun and M. Gateau, The Physical and Mechanical Properties of Dragon-Pechiney G5 Graphite, translated and edited by L. W. Graham, CON/WIN/52330, Sud-Aviation, Paris, France, 1964.

28. R. Taylor et al., The Mechanical Properties of Reactor Graphite, Carbon, 5(5): 519-531 (November 1967).

29. R. B. Dull, Research and Development on Advanced Graphite Materials, Vol. XXVI. Physical Properties of Some Newly Developed Graphite Grades, Technical Documentary Report No. WADD-TR-6I-72, National Carbon Company, June 1963.

30. J. D. Woodward, An Investigation of the Mechanical Behavior of Grades RVD and AGOT Graphites, USAEC Report TID-23288, Southern Research Institute, Apr. 20, 1966.

31. M. F. Berard and L. M. Swope, Elevated Temperature Properties of Grade ATJ and H-249 Graphite, Report MF-548, Aerojet-General Corporation, July 31, 1964.

32. P. G. Lafyatis, C. W. Waters, and R. B. Dull, Final Report on the Development and Evaluation of Large-Scale RVA and CFZ Graphite, Technical Report AFML-TR-65-183, Vol. II, TWR Systems, July 1965.

33. H. S. Starret, The Thermal Expansion and Tensile Properties of Two Types of POCO Graphites, Final Report to Douglas Aircraft Company, Inc., Missile and Space Systems Division, by Southern Research Institute, Dec. 30, 1966.

34. V. Kachur and H. C. Nicholson, Isostatically Molded P-03 Graphite for Large Structures, Report WANL-TME-1190, Westinghouse Astronuclear Laboratory, June 29, 1965.

35. W. I. Greenstreet, Mechanical Properties of Artificial Graphites - A Survey Report, USAEC Report ORNL-4327, Oak Ridge National Laboratory, December 1968 .

36. P. Wagner and L. B. Dauelsbery, The Thermal Conductivity of ZTA Graphite, Carbon, 5: 271-279 (1967).

37. P. Wagner and L. B. Dauelsbery, The Thermal Conductivity of SX-5 Graphite, Carbon, 6: 373-380 (1967).

38. Y. S. Touloukian, Thermophysical Properties of High Temperature Solid Materials, Vol. 1: Elements, Macmillan, New York, 1967. 
39. Data supplied by Poco Graphite, Inc.

40. C. Y. Ho et al., Thermal Conductivity of Selected Materials, Part 2, Report NSRDS-NBS 16, National Bureau of Standards, U.S. Government Printing Office, Washington, D.C., February 1968.

41. D. L. McElroy, Oak Ridge National Laboratory, personal communication to G. T. Yahr, Oak Ridge National Laboratory.

42. Industrial Grophite Engineering Handbook, Union Carbide Corporation, New York, 1965. 


\section{Acknowledgments}

The author gratefully acknowledges the assistance of many of his fellow workers at the Oak Ridge National Laboratory. F. J. Witt, J.M. Corum, W. L. Greenstreet, and R. N. Lyon made many valuable suggestions during this investigation. Helpful advice on instrumentation problems was received from J. E. Smith, L. H. Thacker, and W. F. Johnson. H. A. MacColl, D. T. Godwin, and Ray Cooper assisted in running the tests.

The author is grateful to Harold Hessing for suggesting that the staircase method might be applicable to the thermal shock test. He also thanks his graduate committee members for their time spent reviewing this thesis, especially Professor A. Mathews. The assistance of Mrs. Ann Savolainen in editing this report is gratefully acknowledged. 
-

- 


\author{
Appendix A \\ PROPERTIES OF THE GRAPHITES INVESTIGATED
}

Available data on the 21 grades, or types, of graphite included in this investigation are given in Table A.I, which lists the manufacturer's grade designation, manufacturer, principal filler material, maximum particle size, type of binder, forming method, graphitization temperature, billet size, and density. Even these basic data were not available in many instances, as indicated by the blank spaces in the table. The grain sizes range from 0.0008 to $0.03 \mathrm{in.}$, and the graphitization temperatures range from 4170 to $5250^{\circ} \mathrm{F}$. Six of the graphites were extruded and 13 were molded. A relatively new technique, called hot-working, was used to make ZTA graphite, which has with-grain properties in the isotropic plane, as does molded graphite, but is much more anisotropic than molded graphite.

Mechanical Properties of Graphites

Graphite is a brittle material at ordinary temperatures and has a nonlinear stress-strain curve. The with-grain stress-strain curves for RVD graphite at various temperatures ranging from room temperature to $5500^{\circ} \mathrm{F}$ are shown in Fig. A.I. The effect of temperature on the stressstrain data is typical for polycrystalline graphites. At temperatures above about $4000^{\circ} \mathrm{F}$, creep and strain-rate effects are of considerable magnitude.

Because of the brittle nature of graphite, tensile tests must be conducted very carefully or the recorded strength will be well below the true tensile strength. The reported values of the with-grain tensile strength of ATJ graphite at room temperature range from 1790 psi (Ref. 25) to 4200 psi (Ref. 21). An ASTM standard for tensile testing of graphite is currently being evolved so that tensile strengths reported by different investigators will be more comparable. ${ }^{2}$ The flexure test is sometimes used instead of the tensile test, but because of the nonlinearity of the stressstrain curve and differences in the tensile and compressive stress-strain curves, proper analysis of the data is difficult. ${ }^{23}$ 
Table A.1. Information on Manufacture of Graphite

\begin{tabular}{|c|c|c|c|c|c|c|c|c|}
\hline Grade & Manufacturer & Filler & $\begin{array}{c}\text { Maximum } \\
\text { Particle } \\
\text { Size } \\
\text { (in.) }\end{array}$ & Binder & $\begin{array}{l}\text { Forming } \\
\text { Method }\end{array}$ & $\begin{array}{c}\text { Graphitization } \\
\text { Temperature } \\
\left({ }^{\circ} \mathrm{F}\right)\end{array}$ & $\begin{array}{l}\text { Billet Size } \\
\text { (in.) }\end{array}$ & $\begin{array}{l}\text { Density } \\
(\mathrm{g} / \mathrm{cc})\end{array}$ \\
\hline ZTA & Union Carbide & Petroleum coke & 0.006 & Coal-tar pitch & Hot worked & & $81 / 2$ diam $\times 11$ & 1.92 \\
\hline ATJ & Union Carbide & Petroleum coke & 0.006 & Coal-tar piteh & Molded & & & 1.77 \\
\hline RVA & Union Carbide & $\begin{array}{l}\text { Graphite flour and } \\
\text { thermatomic black }\end{array}$ & 0.03 & $\begin{array}{l}\text { Coal-tar pitch } \\
\text { and sulfur }\end{array}$ & Molded & & & 1.82 \\
\hline RVD & Union Carbide & $\begin{array}{l}\text { Graphite flour and } \\
\text { thermatomic black }\end{array}$ & 0.015 & $\begin{array}{l}\text { Coal-tar pitch } \\
\text { and sulfur }\end{array}$ & Molded & 5070 & 23 diam $\times 15$ & 1.86 \\
\hline AGOT & Union Carbide & Petroleum coke & 0.032 & Coal-tar pitch & Extruded & 5070 & $18 \times 18 \times 240$ & 1.69 \\
\hline $\mathrm{AXM}$ & Poco & & 0.0006 & & Molded & 4170 & 2 diam $\times 12$ & 1.74 \\
\hline$A X F-5 Q$ & Poco & & 0.0006 & & Molded & 4530 & 2 diam $\times 12$ & 1.81 \\
\hline AXF-9Q & Poco & & 0.0006 & & Molded & 5250 & 2 diam $\times 12$ & 1.80 \\
\hline AXM-9Q & Poco & & 0.0006 & & Molded & 5250 & 2 diam $\times 12$ & 1.75 \\
\hline AXZ-9Q & Poco & & 0.0006 & & Molded & 5250 & 2 diam $\times 12$ & 1.58 \\
\hline BXZ-9Q & Poco & & & & Molded & 5250 & 2 diam $\times 12$ & 1.60 \\
\hline 2033 & Stackpole & $\begin{array}{l}\text { Graphite flour } \\
\text { with high CTE }\end{array}$ & & & Molded & & $41 / 2$ diam $\times 5$ & 1.63 \\
\hline P03 & Pure carbon & $\begin{array}{l}\text { Petroleum coke and } \\
\text { graphite flour }\end{array}$ & & Coal-tar pitch & Molded & & 7 diam $\times 72$ & 1.78 \\
\hline $780 \mathrm{~s}$ & Speer & & 0.008 & & Extruded & & 5 diam $\times 9$ & 1.80 \\
\hline SX5 & Speer & Petroleum coke & 0.032 & Coal-tar pitch & Extruded & 5070 & $31 / 2 \times 18 \times 20$ & 1.66 \\
\hline 9326 & Speer & Petroleum coke & 0.0008 & Coal-tar pitch & Molded & & $2 \times 4 \times 5$ & 1.90 \\
\hline H2O5 & Great Lakes & & 0.006 & & Molded & & $9 \times 20 \times 24$ & 1.73 \\
\hline $\begin{array}{l}\text { British iso- } \\
\text { tropic }\end{array}$ & & Petroleum coke & 0.04 & Coal-tar pitch & Extruded & & $\begin{array}{l}16 \text { OD } \times 51 / 2 \\
I D \times 35\end{array}$ & 1.89 \\
\hline G5 & Pechney & Graphite flour & 0.01 & Coal-tar pitch & Extruded & & $31 / 4 \mathrm{diam} \times 17$ & 1.84 \\
\hline Graphitite G & Carborundum & Petroleum coke & 0.008 & Coal-tar pitch & Extruded & & $\begin{array}{l}3 / 4 \text { diam } \times 6 \\
2 \text { diam } \times 12 \\
4 \text { diam } \times 24\end{array}$ & 1.89 \\
\hline $\mathrm{W}$ & Carborundum & & & & & & 4 diam $\times 24$ & 1.76 \\
\hline
\end{tabular}

${ }^{a}$ CTE $=$ coefficient of thermal expansion. 


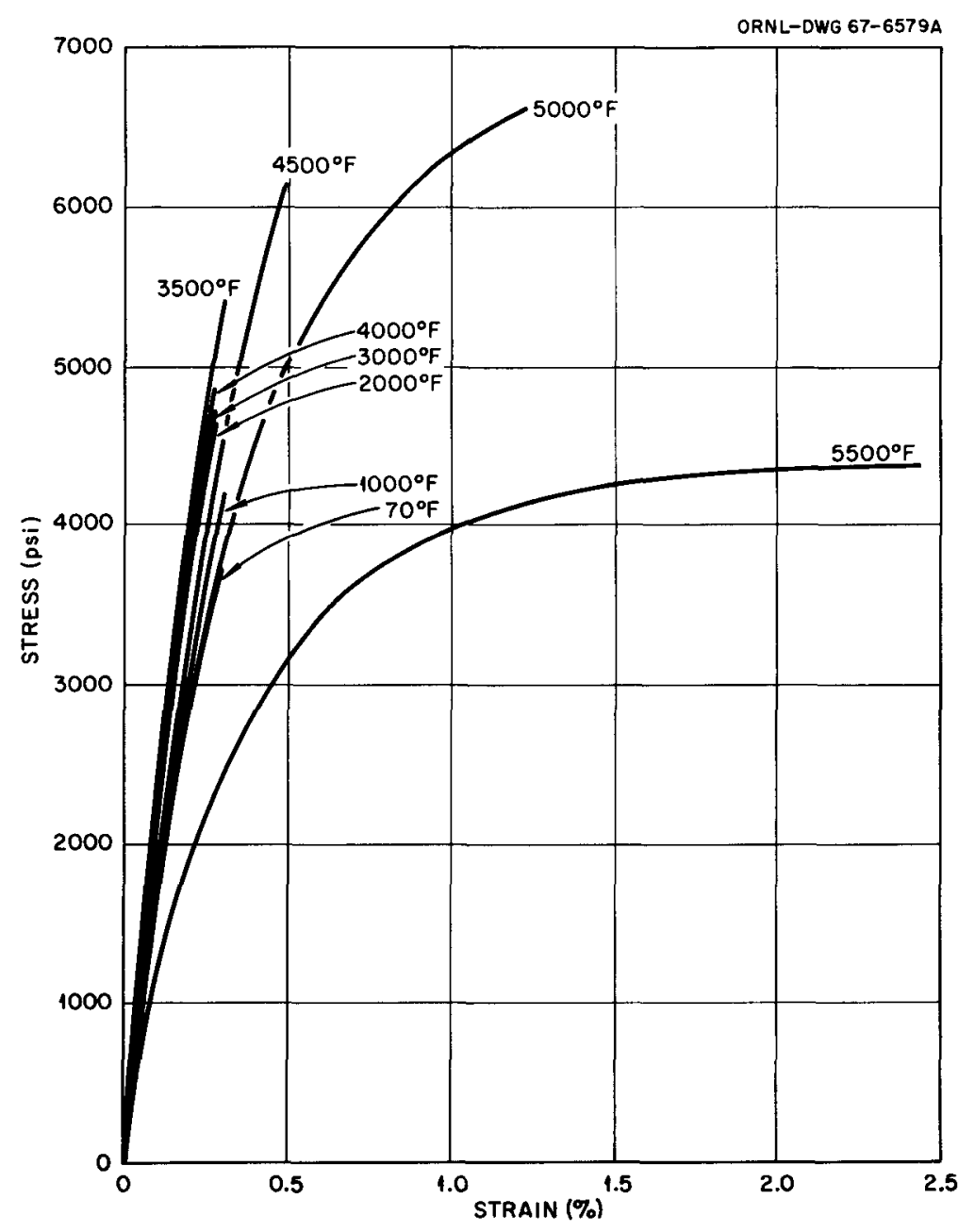

Fig. A.l. With-Grain Tensile Curves for RVD Graphite at Various Temperatures.

Even a simple mechanical property such as Young's modulus is difficult to measure. The initial part of the stress-strain curve is nonlinear, so the tangent to the curve at zero stress is usually taken to be the modulus. However, the tangent drawn depends on the scale to which the curve is drawn and on the judgment of the person who selects the tangent. For instance, with-grain modulus values for ATJ graphite at room temperature range from $0.80 \times 10^{6} \mathrm{psi}$ (Ref. 21) to $1.67 \times 10^{6} \mathrm{psi}$ (Ref. 19).

Available room-temperature mechanical properties of the 21 types of graphite investigated are given in Table A.2. These data were obtained from Refs. 19 and 23-28. The modulus of elasticity, tensile strength, and 
Table A.2. Room-Temperature Mechanical Properties of Graphite

\begin{tabular}{|c|c|c|c|c|c|c|}
\hline \multirow{2}{*}{ Grade } & \multicolumn{2}{|c|}{$\begin{array}{l}\text { Modulus of Elas- } \\
\text { ticity (psi) }\end{array}$} & \multicolumn{2}{|c|}{$\begin{array}{c}\text { Tensile Strength } \\
\text { (psi) }\end{array}$} & \multicolumn{2}{|c|}{$\begin{array}{l}\text { Modulus of Rup- } \\
\text { ture (psi) }\end{array}$} \\
\hline & $\begin{array}{l}\text { With } \\
\text { Grain }\end{array}$ & $\begin{array}{l}\text { Across } \\
\text { Grain }\end{array}$ & $\begin{array}{l}\text { With } \\
\text { Grain }\end{array}$ & $\begin{array}{l}\text { Across } \\
\text { Grain }\end{array}$ & $\begin{array}{l}\text { With } \\
\text { Grain }\end{array}$ & $\begin{array}{l}\text { Across } \\
\text { Grain }\end{array}$ \\
\hline & $\times 10^{6}$ & $\times 10^{6}$ & & & & \\
\hline $\begin{array}{l}\text { ZTA } \\
\text { ATJ } \\
\text { RVA } \\
\text { RVD } \\
\text { AGOT }\end{array}$ & $\begin{array}{l}2.72 \\
1.65 \\
2.01 \\
2.32 \\
1.73\end{array}$ & $\begin{array}{l}0.66 \\
1.17 \\
1.30 \\
1.36 \\
0.95\end{array}$ & $\begin{array}{l}4,400 \\
3,850 \\
3,300 \\
4,000 \\
1,570\end{array}$ & $\begin{array}{r}1,630 \\
3,000 \\
2,400 \\
2,840 \\
930\end{array}$ & $\begin{array}{l}5,400 \\
4,010 \\
3,700 \\
4,700 \\
2,280\end{array}$ & $\begin{array}{l}2,425 \\
3,580 \\
2,900 \\
3,100\end{array}$ \\
\hline $\begin{array}{l}\text { AXM } \\
\text { AXY-5Q } \\
\text { AXF-9Q } \\
\text { AXM-9Q } \\
\text { AXZ-9Q } \\
\text { BXZ-9Q }\end{array}$ & $\begin{array}{l}1.7 \\
1.97 \\
1.69\end{array}$ & $\begin{array}{l}1.6 \\
1.97 \\
1.69\end{array}$ & $\begin{array}{r}7,400 \\
10,170 \\
5,530\end{array}$ & $\begin{array}{r}7,400 \\
10,170 \\
5,530\end{array}$ & $\begin{array}{r}8,000 \\
12,000 \\
10,450 \\
4,500\end{array}$ & $\begin{array}{r}8,000 \\
12,000 \\
10,450 \\
4,500\end{array}$ \\
\hline \multicolumn{7}{|l|}{2033} \\
\hline $\mathrm{PO}$ & 1.5 & 1.5 & 5,000 & 5,000 & 10,000 & 10,000 \\
\hline $\begin{array}{l}780 S \\
\text { SX5 } \\
9326\end{array}$ & $\begin{array}{l}1.28 \\
1.5\end{array}$ & 1.14 & $\begin{array}{l}2,400 \\
5,000\end{array}$ & 1,700 & $\begin{array}{l}4,040 \\
4,550 \\
6,500\end{array}$ & $\begin{array}{l}4,325 \\
7,500\end{array}$ \\
\hline $\mathrm{H} 205$ & 1.6 & 1.4 & 3,200 & 2,800 & 4,500 & 4,000 \\
\hline British isotropic & 1.65 & 1.51 & 2,150 & 2,000 & & \\
\hline G5 & 2.03 & 1.02 & 4,000 & 2,200 & 4,200 & 2,860 \\
\hline $\begin{array}{l}\text { Graphitite G } \\
\text { W }\end{array}$ & $\begin{array}{l}1.5 \\
1.8\end{array}$ & $\begin{array}{l}1.0 \\
1.3\end{array}$ & $\begin{array}{l}3,300 \\
2,400\end{array}$ & 1,400 & $\begin{array}{l}5,500 \\
4,400\end{array}$ & 3,000 \\
\hline
\end{tabular}

modulus of rupture are recorded for both the with-grain and across-grain directions. These data show how anisotropic the various types of graphites are. Some of the materials are apparently isotropic. The most anisotropic graphite included in the study was ZTA graphite.

The dynamic modulus of elasticity is plotted as a function of temperature for five of the graphites in Fig. A.2. These data came from Refs. 27 and 29. The with-grain modulus is shown for the molded grades (ZTA, RVA, ATJ, and RVD) and the across-grain modulus is given for G5 


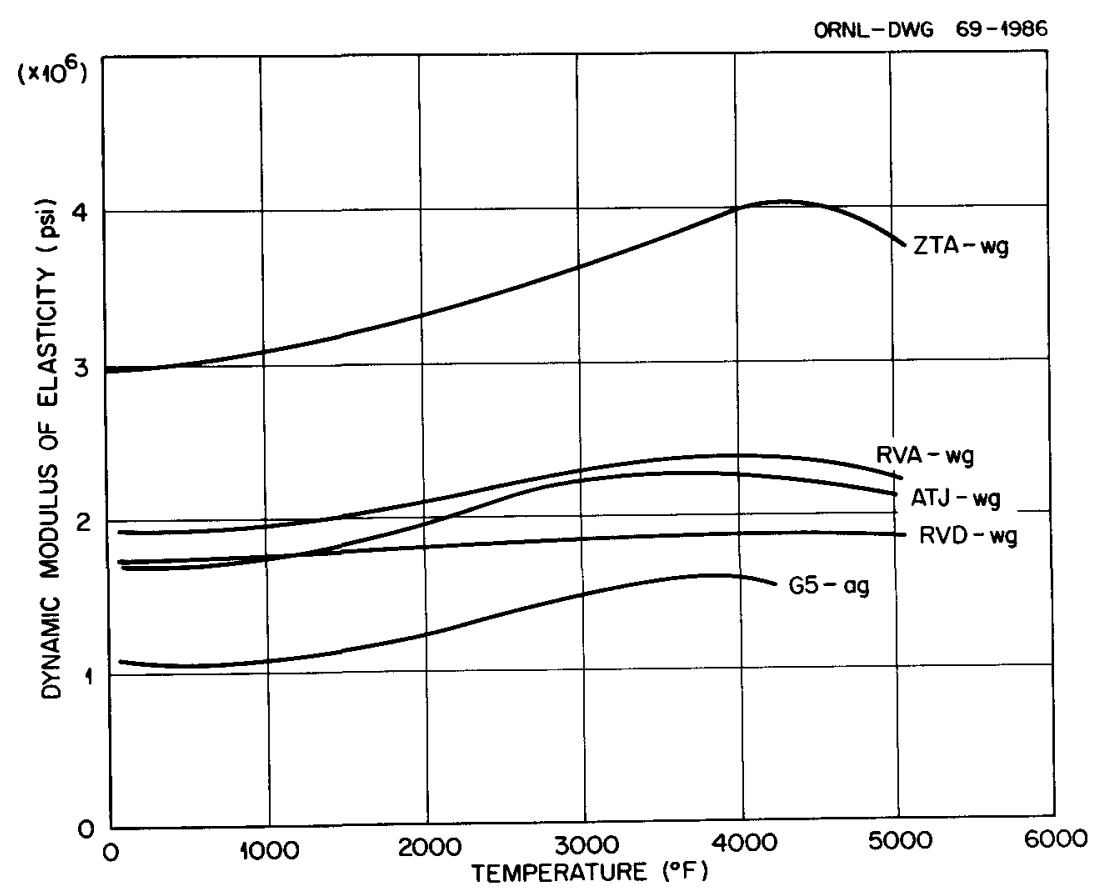

Fig. A.2. Temperature Dependence of Dynamic Modulus of Elasticity.

graphite, which is extruded. The dynamic modulus is found by determining the resonant frequency of a sample.

The static modulus is determined by measuring the initial slope of the stress-strain curve and should be about the same as the dynamic modulus. The static moduli of several graphites are plotted versus temperature in Fig. A.3. These data were obtained from Refs. 4, 21, and 29-33. With-grain modulus values for ATJ graphite from three different sources are shown, and they are in poor agreement. However, the highest of the three static modulus curves for ATJ graphite is in good agreement with the dynamic modulus curve for ATJ graphite in Fig. A.2. The static and dynamic moduli for RVD graphite also agree.

The tensile strengths of ten graphites are plotted as functions of temperature in Fig. A.4. These data were obtained from Refs. 4, 21, 27, 30 , and $32-34$. A wide range of strengths is represented in the figure. However, all the graphites increased in strength as the temperature increased to at least $4000^{\circ} \mathrm{F}$. 


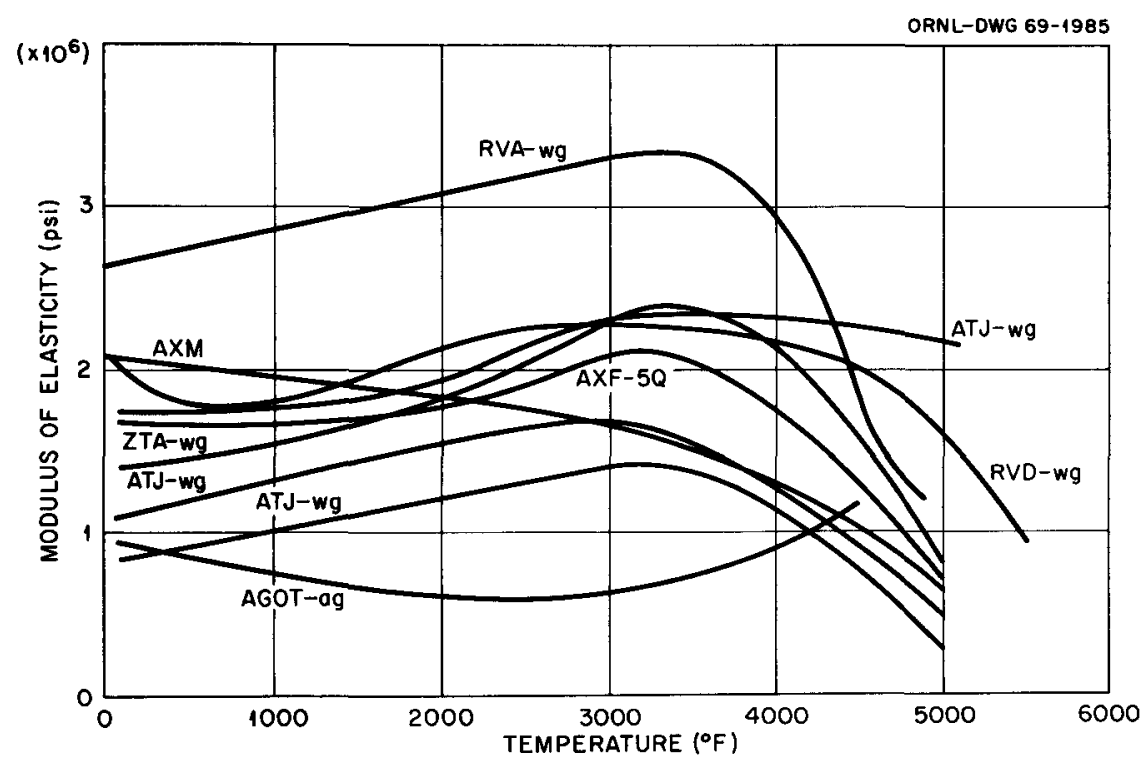

Fig. A.3. Temperature Dependence of Static Modulus of Elasticity.

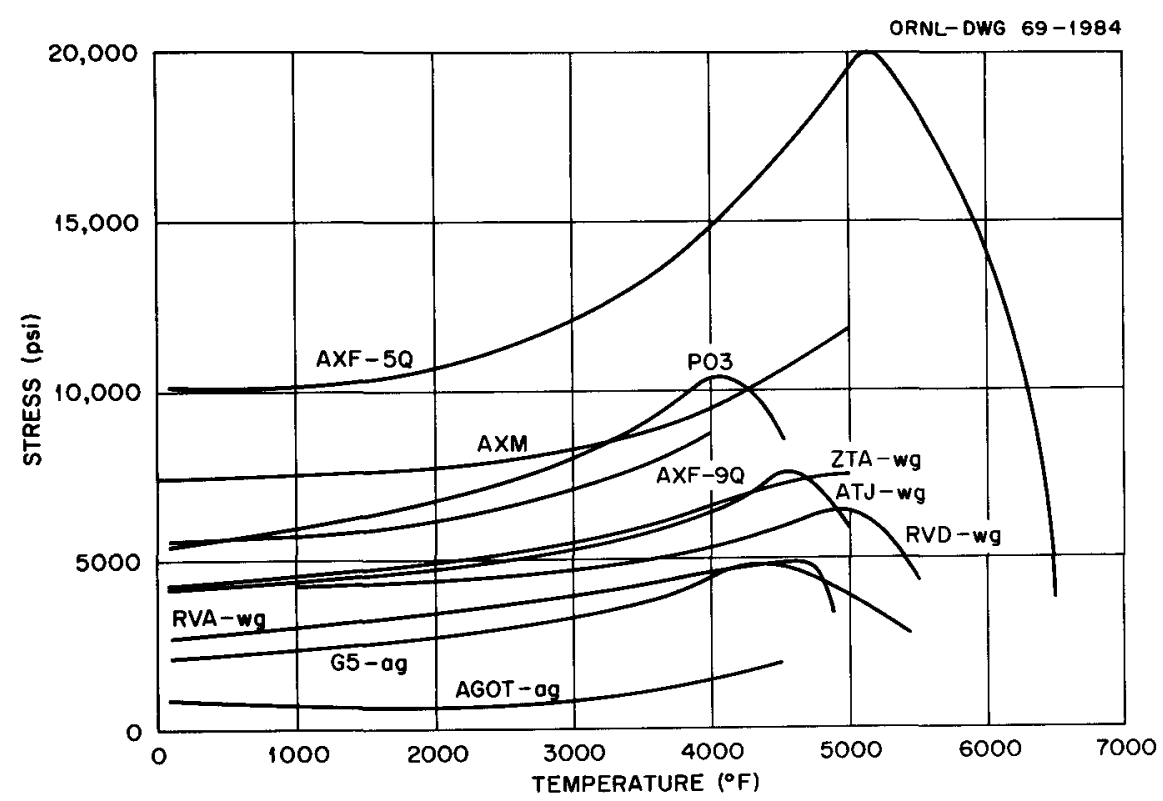

Fig. A.4. Temperature Dependence of Tensile Strength. 
A transversely isotropic material has three strain ratios. The values of the strain ratios for graphite remain approximately constant as the compression stress increases, but in tension the strain ratios decrease slightly as the load increases. ${ }^{35}$ Room-temperature initial strain-ratio values or Poisson's ratios $\left(\nu_{12}, \nu_{13}\right.$, and $\left.\nu_{31}\right)$ for several graphites, which were obtained from Refs. 19 and 23, are given in Table A.3. The subscripts refer to a Cartesian coordinate system where the 1 and 2 directions are in the isotropic plane. The first subscript refers to the direction in which the stress is applied, and the second subscript indicates the direction of the lateral strain. The Poisson's ratio values are small compared with those of most common metals.

\begin{tabular}{llll}
$\begin{array}{c}\text { Table A.3. } \\
\text { Poisson's Ratio Values } \\
\text { for Graphites }\end{array}$ & \multicolumn{3}{c}{ Room-Temperature } \\
& & & \\
Poisson's Ratio \\
\cline { 2 - 4 } Graphite & $v_{12}$ & $v_{13}$ & $v_{31}$ \\
\hline \multirow{2}{*}{ ZTA } & 0.10 & 0.25 & 0.05 \\
ATJ & 0.10 & 0.16 & 0.11 \\
RVA & 0.11 & 0.16 & 0.11 \\
RVD & 0.11 & 0.22 & 0.12 \\
AGOT & 0.10 & 0.04 & 0.08 \\
\hline
\end{tabular}

Thermal Properties of Graphite

The unit thermal expansions of 16 types of graphite due to a temperature increase are plotted against temperature in Fig. A.5. These data were obtained from Refs. 20, 27, 32-34, 36, and 37. Only the expansion in the plane of the thermal shock specimen is shown, except for ZTA graphite; that is, the with-grain expansion is shown for the molded graphites, and the across-grain expansion is shown for the extruded graphites. The ZTA graphite is so anisotropic that the across-grain thermal expansion is the highest expansion exhibited by any of the graphites, and the withgrain thermal expansion is the lowest. The behavior of $\mathrm{PO} 3$ graphite is 


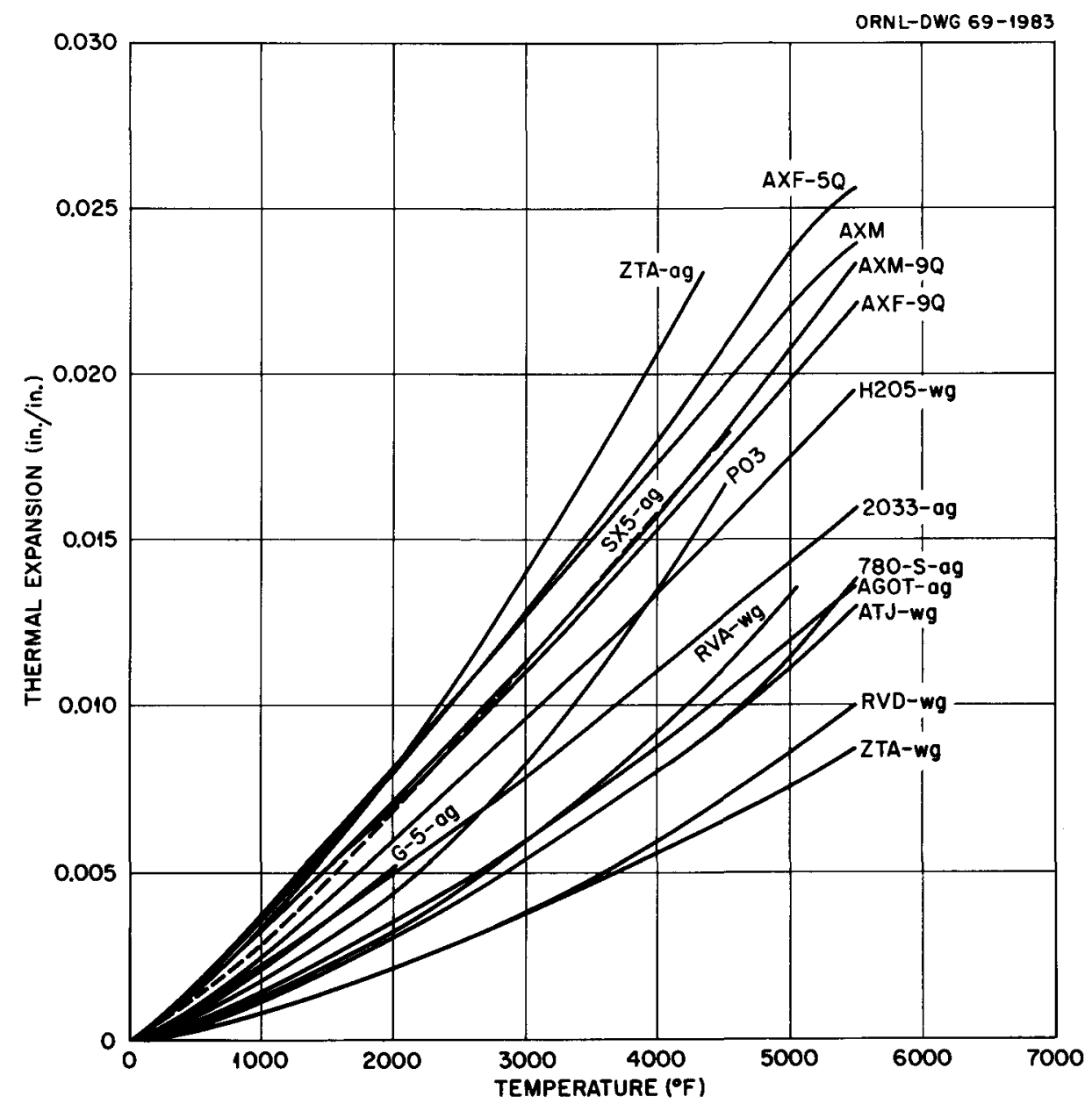

Fig. A.5. Thermal Expansion of Sixteen Types of Graphite.

peculiar in that the coefficient of thermal expansion increases at a much higher rate than for the other graphites. It is also interesting that the AXF-5Q and AXM graphites show inflexions at about $5000^{\circ} \mathrm{F}$.

Graphite has a relatively high thermal conductivity that is higher in the with-grain direction than in the across-grain direction. Thermal conductivity data as a function of temperature are shown for several types of graphite in Fig. A.6. These data were obtained from Refs. 4, 27, 32, 34, and 36-4l. Data were available only over a very limited range for several of the graphites. The thermal conductivity decreases markedly as the temperature increases. 


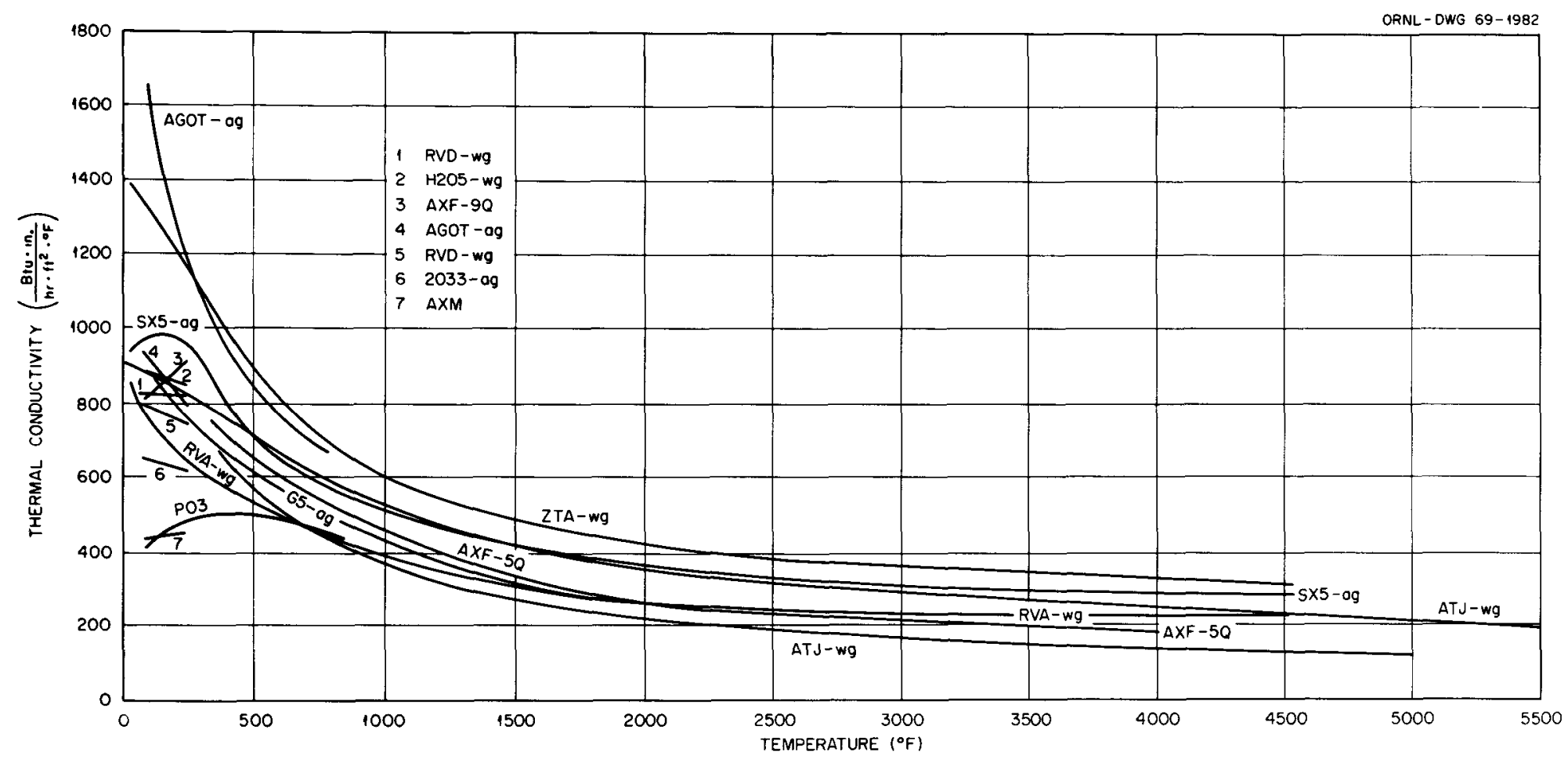

Fig. A.6. Thermal Conductivity of Graphite. 
The values of specific heat, which are given as a function of temperature in Fig. A.7, are essentially the same for all graphites. These data are from Ref. 42.

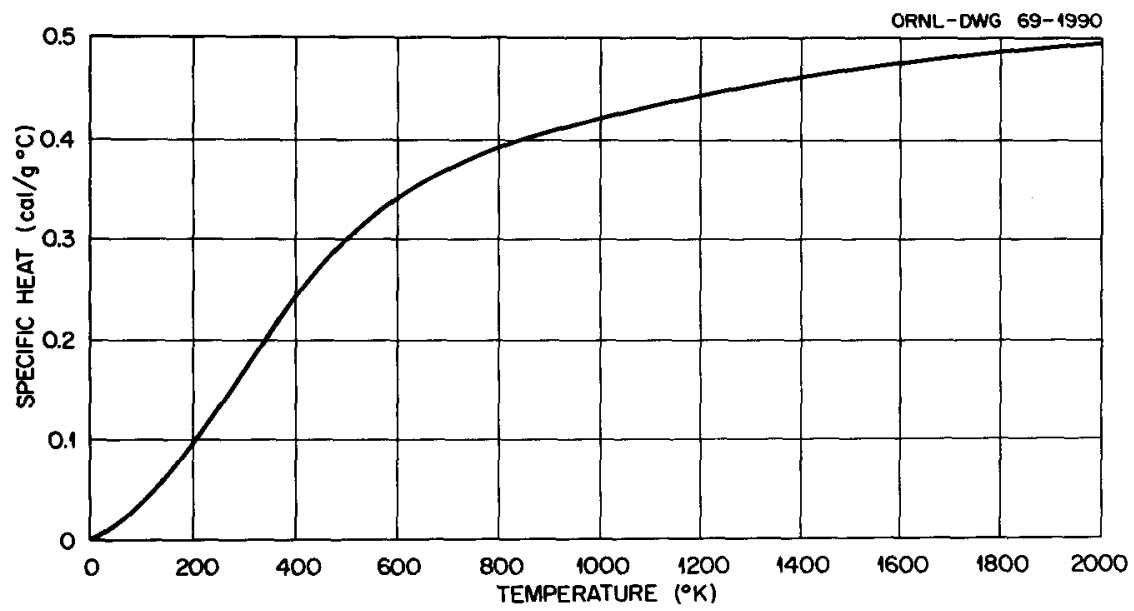

Fig. A.7. Specific Heat of Graphite. 


\author{
ORNL-4467 \\ UC-80 - Reactor Technology
}

\title{
Internal Distribution
}

I. S. E. Beall

2. R. J. Beaver

3. J. W. Bryson

4. J. P. Callahan

5. S. J. Chang

6. C. W. Collins

7. J. L. Cook $(Y-12)$

8. F. L. Culler

9. R. W. Derby

10. R. G. Donnelly

Il. F. J. Furman

12. D. I. Gray

13-17. B. L. Greenstreet

18. R. C. Gwaltney

19. F. F. Haywood

20. D. M. Hewette

21. R. F. Hibbs $(Y-12)$

22. H. W. Hoffman

23. A. P. Litman

24. K. C. Liu

25. L. O. Love

26. H. G. MacPherson

27. D. L. McElroy
28. H. A. McLain

29. J. R. McWherter

30. J. G. Merkle

31. S. E. Moore

32. J. M. Napier $(\mathrm{Y}-12)$

33. L. G. Overholser

34. T. W. Pickel

35. M. W. Rosenthal

36. A. W. Savolainen

37. M. J. Skinner

38. R. C. Steffy

39. H. H. Stone

40. D. A. Sundberg

41-120. D. B. Trauger

121. P. E. Trent (Y-12)

122. A. M. Weinberg

123. F. J. Witt

124-143. G. T. Yahr

144-146. Central Research Library

147-148. Y-12 Document Reference Section

149-181. Laboratory Records Department

182. Laboratory Records, R.C.

\section{External Distribution}

183. C. A. Anderson, Westinghouse Astronuclear Laboratory, Pittsburgh, Pa.

184. R. W. Andrae, Los Alamos Scientific Laboratory

185. P. E. Armstrong, Los Alamos Scientific Laboratory

186. H. W. Babel, McDonald-Douglas Astronautics, 300 Ocean Park, Santa Monica, Calif.

187. W. A. Bauer, Speer Carbon Company, St. Marys, Pa.

188. H. W. Behrman, RDT Site Office, ORNL

189. J. R. Bohn, TWR Systems, Redondo Beach, Calif.

190. S. A. Bortz, IIT Research Institute, Chicago, Ill.

191. H. L. Brammer, SNPO-C, NASA Lewis Research Center, Cleveland, Ohio

192. D. W. Bridges, Philco-Ford Corporation

193. W. Brussalis, Westinghouse Astronuclear Laboratory, Pittsburgh, Pa.

194. A. E. Carden, University of Alabama, Tuscaloosa, Ala.

195. R. K. Carlson, Poco Graphite, Inc., Dallas, Texas

196. L. C. Corrington, SNPO-C, NASA Lewis Research Center, Cleveland, Ohio

197. Jack Cully, SNPO-A, c/O USAEC, P.O. Box 5400, Albuquerque, N.M. 
198. J. F. Demendi, PURE Carbon Company, Ine., St. Marys, Pa.

199. R. J. Dietz, Los Alamos Scientific Laboratory

200. G. B. Engle, Gulf General Atomic, San Diego, Calif.

201. D. M. Forney, Air Force Materials Laboratory (MAC), WrightPatterson Air Force Base, Ohio

202. E. L. Foster, Jr., Battelle Memorial Institute, Columbus, Ohio

203. J. E. Fox, AEC Headquarters, Washington, D.C.

204. L. L. France, Westinghouse Astronuclear Laboratory, Pittsburgh, Pa.

205. C. W. Funk, Nuclear Rocket Operations, Aerojet-General Corporation, Sacramento, Calif.

206. E. A. Henne, Westinghouse Astronuclear Laboratory, Pittsburgh, Pa.

207. Harold Hessing, SNPO-A, c/o Los Alamos Scientific Laboratory, GMB Division, Los Alamos, N.M.

208. A. N. Holden, Westinghouse Astronuclear Laboratory, Pittsburgh, Pa.

209. Gary Kaveny, Aerojet-General Corporation, Sacramento, Calif.

210. W. Kellner, Stackpole Carbon Company, St. Marys, Pa.

2l1. H. M. Killmar, The Carborundum Company, Graphite Products Division, Sanborn, N.Y.

212. C. R. King, Los Alamos Scientific Laboratory

213. Fred Kirkhart, Westinghouse Astronuclear Laboratory, Pittsburgh, Pa.

214. N. Krishnamurthy, Auburn University, Auburn, Ala.

215. W. J. Larkin, AEC, ORO

216. R. G. Lawton, Los Alamos Scientific Laboratory

217. C. W. Lee, University of Tennessee, Knoxville, Tenn.

218. Bruce Leonard, Douglas Aircraft Company, 300 Ocean Park Blvd., Santa Monica, Calif.

219. J. J. Lombardo, SNPO, NASA Lewis Research Center, Cleveland, Ohio

220. J. D. Lubahn, Colorado School of Mines, Golden, Colo.

221. L. L. Lyon, Los Alamos Scientific Laboratory

222. H. G. Maahs, NASA, Langley Research Center, Langley Station, Hampton, Va.

223. D. P. MacMillan, Los Alamos Scientific Laboratory

224. M. Manjoine, Westinghouse Astronuclear Laboratory, Pittsburgh, Pa.

225. H. E. Martens, Jet Propulsion Laboratory, Pasadena, Calif.

226. A. Matthews, University of Tennessee, Knoxville, Tenn.

227. R. L. Maxwell, University of Tennessee, Knoxville, Tenn.

228. W. J. McAfee, University of Tennessee, Knoxville, Tenn.

229. J. T. Meers, Parma Research Center, Cleveland, Ohio

230. R. A. Mercuri, Union Carbide Corporation, Parma Technical Center, Cleveland, Ohio

231. G. A. Meyer, Stackpole Carbon Company, St. Marys, Pa.

232-233. J. E. Morrissey, SNPO, AEC, Washington

234. R. E. Nightingale, Pacific Northwest Laboratory, Richland, Wash.

235. C. D. Pears, Southern Research Institute, Birmingham, Ala.

236. Hui Pih, Department of Engineering Mechanics, University of Tennesse, Knoxville, Tenn.

237. C. A. Pratt, Air Force Materials Laboratory, Wright-Patterson Air Force Base, Ohio

238. W. G. Ramke, Air Force Materials Laboratory, Wright-Patterson Air Force Base, Ohio

239. R. D. Reiswig, Los Alamos Scientific Laboratory 
240-249. J. C. Rowley, Los Alamos Scientific Laboratory

250. W. S. Scheib, SNPO, AEC, Washington

251. W. H. Schmitt, Sandia Corporation, Albuquerque, N.M.

252. R. W. Schroeder, SNPO-C, NASA Lewis Research Center, Cleveland, Ohio

253. F. C. Schwenk, SNPO, AEC, Washington

254. E. J. Seldin, Parma Research Center, Cleveland, Ohio

255. L. R. Shobe, University of Tennessee, Knoxville, Tenn.

256. R. H. Singleton, Westinghouse Astronuclear Laboratory, Pittsburgh, $\mathrm{Pa}$.

257. F. A. Smith, Coal, Coke, and Chemicals Division, United States Steel Corporation, Applied Research Laboratory, Monroeville, Pa.

258. M. C. Smith, Los Alamos Scientific Laboratory

259. G. B. Spence, Parma Research Center, Cleveland, Ohio

260. E. R. Stover, GE-RSD, Philadelphia, Pa.

261. J. L. Swanson, Westinghouse Astronuclear Laboratory, Pittsburgh, Pa.

262. J. A. Swartout, Union Carbide Corporation, New York, N.Y.

263. Milt Swope, Aerojet-General Corporation, Sacramento, Calif.

264. J. S. Theilacker, Westinghouse Astronuclear Laboratory, Pittsburgh, $\mathrm{Pa}$.

265. D. E. Thomas, Materials and Fuel Facility, Westinghouse Astronuclear Laboratory, Pittsburgh, Pa.

266. N. R. Thielke, SNPO, NASA Lewis Research Center, Cleveland, Ohio

267. G. L. Tingey, Battelle Pacific Northwest Laboratory, Richland, Wash.

268. P. L. Walker, Jr., Pennsylvania State University, University Park, Pa.

269. Tu-Lung Weng, Parma Research Center, Cleveland, Ohio

270. E. M. Woodruff, Pacific Northwest Laboratory, Richland, Wash.

271. Laboratory and University Division, AEC, ORO

272-479. Given distribution as shown in TID-4500 under Reactor Technology category (25 copies - CFSTI) 